\title{
Silver nanoparticles: A novel antibacterial agent for control of Cronobacter sakazakii
}

\author{
Hui Wang, ${ }^{* 1}$ Yujun Jiang, ${ }^{* 1}$ Yashuo Zhang, ${ }^{*}$ Ziwei Zhang, ${ }^{*}$ Xinyan Yang, ${ }^{*}$ Md. Aslam Ali, ${ }^{*} \dagger$ Edward M. Fox, \\ Kari S. Gobius, $\ddagger$ and Chaoxin Man*2 \\ *Key Laboratory of Dairy Science, Ministry of Education, College of Food Science and Engineering, Northeast Agricultural University, Harbin, \\ China, 150030 \\ †Department of Agro-Processing, Bangabandhu Sheikh Mujibur Rahman Agricultural University, Gazipur-1706, Bangladesh \\ †CSIRO Agriculture and Food, Werribee VIC 3030, Australia
}

\section{ABSTRACT}

Silver nanoparticles (AgNP) have been widely applied because of their broad spectrum of antimicrobial activities against bacteria, fungi, and viruses. However, little research has been done to evaluate their effects on Cronobacter sakazakii, an opportunistic pathogen usually infecting infants and having a high fatality rate. The aims of this work were to investigate the antibacterial property of novel, synthesized, positively charged silver nanoparticles against C. sakazakii and to discuss the potential antibacterial mechanisms involved. In this study, the spherical and face-centered cubic silver nanoparticles had a mean particle size of $31.2 \mathrm{~nm}$ and were synthesized by reducing $\mathrm{Ag}^{+}$using citrate and dispersed by glycerol and polyvinylpyrrolidone (PVP) under alkaline conditions. Minimum inhibitory concentrations (MIC) and inhibition zone tests showed that the AgNP exhibited strong antibacterial activity against 4 tested C. sakazakii strains with mean MIC of 62.5 to $125 \mathrm{mg} / \mathrm{L}$ and average inhibition zone diameters of 13.8 to $16.3 \mathrm{~mm}$. Silver nanoparticles caused cell membrane injury accompanied by adsorption of AgNP onto the cell surface, as shown by changes in cell morphology, cell membrane hyperpolarization, and accelerated leakage of intracellular reducing sugars and proteins outward from the cytoplasm. In addition, dysfunction of the respiratory chain was induced after treatment with AgNP, which was supported by a decrease in intracellular ATP and inhibition of related dehydrogenases. This research indicates that AgNP could be a novel and efficient antibacterial agent to control C. sakazakii contamination in environments producing powdered infant formulas from milk.

Received June 21, 2018.

Accepted August 24, 2018.

${ }^{1}$ These authors contributed equally to this work.

${ }^{2}$ Corresponding author: mcxwh2006@qq.com
Key words: silver nanoparticles, Cronobacter sakazakii, cell membrane, antibacterial mechanism

\section{INTRODUCTION}

Cronobacter sakazakii belongs to the Cronobacter genus of the Enterobacteriaceae family (Iversen et al., 2007 ); it is a life-threatening opportunistic pathogen that is gram-negative, motile, peritrichous, non-sporeforming, and facultatively anaerobic. The pathogen is widespread and has been isolated from various food substrates, including vegetables (mixed salad), meat and meat products, tea, dry ingredients, milk, and cheese (Beuchat et al., 2009). Particularly, powdered infant formula (PIF) is among the most commonly known sources of infection and can be contaminated by C. sakazakii from food processing environments (air, ground, and water), processing ingredients, accessories, or capping materials during PIF production (Kandhai et al., 2004). In clinical research, C. sakazakii is epidemiologically linked to neonatal and infant infections in immunocompromised individuals, especially preterm and low-birth-weight infants (Healy et al., 2010). Clinical symptoms of infection in infants include meningitis, bacteremia, and severe forms of necrotizing enterocolitis, with a mortality rate ranging from 40 to $80 \%$ (Friedemann, 2009; Endersen et al., 2017).

Cronobacter sakazakii has a strong ability to resist dry and osmotic stresses and it exhibits thermal and acid-base tolerance (Riedel and Lehner, 2007; Yemiş et al., 2011). These characteristics are thought to contribute to the survival of $C$. sakazakii in PIF products. To control contamination by $C$. sakazakii in the food industry, various interventions have been proposed and developed, including UV-near infrared radiation, photon hydroxylation technology, gaseous ozone, ultrasound with thermal treatment, and some natural antimicrobials such as heat-labile bacteriocins and syringic acid (Adekunte et al., 2010; Awaisheh et 
al., 2013; Torlak and Sert, 2013; Ha and Kang, 2014; Shi et al., 2016). However, these methods are not able to efficiently eliminate bacteria from food processing surfaces due to the strong biofilm-forming ability of many bacteria during propagation (Hartmann et al., 2010). With the development of nanomaterials, silver nanoparticles (AgNP) could be a novel antibacterial agent because of their broad spectrum of antimicrobial activities against bacteria, fungi, and viruses (Lara et al., 2011; You et al., 2012).

Silver nanoparticles are metal nanoparticles with a size distribution from 1 to $100 \mathrm{~nm}$ in 3-dimensional space, and AgNP have generated significant interest as effective antimicrobial agents in recent years (El-Naggar et al., 2017; Chai et al., 2018). Silver nanoparticles exhibit strong antibacterial activity against Escherichia coli, Staphylococcus aureus, Vibrio cholerae, Pseudomonas aeruginosa, Eberthella typhi, and Bacillus subtilis (Morones et al., 2005; Ruparelia et al., 2008; Ramalingam et al., 2016; Gomaa, 2017). The antibacterial property depends on the size distribution, crystal structure, and surface zeta potential of silver nanoparticles (Pal et al., 2007; Carlson et al., 2008). El-Naggar et al. (2017) hypothesized that Ag nanoparticles cause cell death due to a decrease in cellular ATP production and DNA damage.

Although silver nanoparticles have been evaluated against various microorganisms, their antibacterial activity against $C$. sakazakii is rarely reported. The mechanisms related to the role of cell membrane and the respiratory chain of $C$. sakazakii remain unclear and require further investigation. Understanding the mechanisms of antibacterial activity is important in developing intervention strategies for the control of $C$. sakazakii in the manufacturing environment. In this study, silver nanoparticles were synthesized based on the chemical reduction method, using citrate as reducing agent and glycerol and polyvinylpyrrolidone (PVP) as stabilizers. Characteristics of silver nanoparticles were determined by UV-visible (UV-Vis) absorption spectroscopy, transmission electron microscopy (TEM), X-ray diffraction (XRD), Fourier transform infrared spectroscopy (FT-IR), and dynamic light scattering (DLS) methods to obtain comprehensive information about surface topography, size distribution, crystal structure, connection of surface functional groups, and surface charge, all of which may contribute to the antibacterial activity of AgNP. Moreover, the antibacterial activity of AgNP against C. sakazakii strains was evaluated according to MIC and inhibition zone tests. Finally, a potential antibacterial mechanism was proposed based on changes in cell morphology, membrane integrity, and the disruption of respiratory chain activity by AgNP.

\section{MATERIALS AND METHODS}

\section{Reagents, Bacterial Strains, and Culture Conditions}

The silver to produce AgNP was from silver nitrate $\left(\mathrm{AgNO}_{3}\right.$, Sinopharm Chemical Reagent Co. Ltd., Shanghai, China), using citrate sodium as the reducing agent (Fuchen Chemical Reagent Factory, Tianjin, China); glycerol and PVP (Sangon Biotech Co. Ltd., Shanghai, China) were used as stabilizers. All chemicals were of analytical grade. Four C. sakazakii strains: ATCC 29544 ${ }^{\mathrm{T}}$, ATCC BAA894, ATCC 29004, and ATCC 12868, were purchased from American Type Culture Collection (ATCC, Manassas, VA) and preserved in our laboratory at $-80^{\circ} \mathrm{C}$. Each strain was inoculated into $20 \mathrm{~mL}$ of Luria-Bertani (LB) medium and incubated for $12 \mathrm{~h}$ at $37^{\circ} \mathrm{C}$ with shaking at $160 \mathrm{rpm}$.

\section{Preparation and Purification of Silver Nanoparticles}

Silver nanoparticles were prepared according to Dey et al. (2015) with some modifications. Briefly, $50 \mathrm{~mL}$ of $1 \mathrm{mmol} / \mathrm{L} \mathrm{AgNO}_{3}$ was added to an Erlenmeyer flask, followed by glycerol and PVP at $1 \%$ (vol/vol), respectively. The reaction system was adjusted to $\mathrm{pH} 8$ by using ammonium hydroxide and the mixture boiled on a thermostatic magnetic stirrer (H01-3; Meiyingpu Instrument Manufacturing Co. Ltd., Shanghai, China). With the stirring speed controlled at $200 \mathrm{rpm}, 2 \mathrm{~mL}$ of sodium citrate $(1 \% \mathrm{wt} / \mathrm{vol})$ was added drop-by-drop over $30 \mathrm{~s}$. The color changed from colorless to yellow and finally to brownish black, which indicates the formation of silver nanoparticles. The nanosilver solution was cooled at $4^{\circ} \mathrm{C}$ immediately and stored overnight at room temperature for intraparticle ripening. Silver nanoparticles were obtained by centrifugation at 9,000 $\times g$ for 15 min using a high-speed refrigerated centrifuge (3K15, Sigma, Steinheim, Germany) and purified with 5 washes of $75 \%$ (vol/vol) alcohol and deionized water.

For further characterization of AgNP, a freeze-dried powder was prepared by mixing the AgNP solution with $50 \mathrm{~m} M$ sucrose solution and freeze-drying using a freeze-dryer (Alpha 1-4 LSCplus, Martin Christ, Osterode am Harz, Germany). The process was as follows: samples were frozen at $-75^{\circ} \mathrm{C}$ to $-80^{\circ} \mathrm{C}$ for $2 \mathrm{~h}$, and then freeze-dried below co-melting point temperature at about $-45^{\circ} \mathrm{C}$ for $8 \mathrm{~h}$ and kept at $10^{\circ} \mathrm{C}$ until freezedrying was completed. The solubility and dispersion of freeze-dried powdered silver nanoparticles were tested. All flasks were soaked in a mixture of concentrated $\mathrm{HNO}_{3}$ (65-68 wt \%) and $\mathrm{HClO}_{4}(70-72$ wt \%) at a volume ratio of $9: 1$ for $12 \mathrm{~h}$ and rinsed with deionized water before use. 


\section{Characterization of AgNP}

Analysis of $U V$-Vis Absorption Spectra. In UV-Vis analysis, the surface plasmon resonance (SPR) peak depends on the size and shape of nanoparticles, with the wavelengths for spherical nanoparticles usually being in the range of 405 to $425 \mathrm{~nm}$, and the wavelength value becomes larger when particle size increases (Sikder et al., 2018). The freeze-dried powder of AgNP was dissolved in deionized water to prepare nanosilver suspensions at different concentrations. Aliquots of $1.5 \mathrm{~mL}$ were taken out to determine the absorption spectrum using a wavelength from 300 to $800 \mathrm{~nm}$ with a UV-visible spectrophotometer (UV-2600, Shimadzu, Tokyo, Japan). The characteristic wavelength at the maximum absorption peak and the full width at half maxima (FWHM) were recorded to characterize the shape and homogeneity of AgNP. The $\mathrm{AgNO}_{3}$ solution was used as a blank control throughout this test.

TEM Analysis. Transmission electron microscopy provides direct information about the morphology, coagulation, and size distribution of AgNP. An ultra-high-resolution transmission electron microscope (H-7500 type, Hitachi, Tokyo, Japan) was used to capture images at the nanometer scale under an accelerating voltage of $100 \mathrm{kV}$. Samples were dropped onto carbon-coated copper grids and dried in darkness for 20 min to complete the physical adsorption process. Then, nanoparticles were observed at magnifications of $200,000 \times$ and $100,000 \times$.

Surface Charge and Size Distribution of AgNP. Surface charge is an important property for synthesized AgNP, influencing interactions with bacteria. Positively charged nanoparticles were showed to have the highest effectiveness against both gram-negative and grampositive bacteria compared with neutral or negatively charged AgNP (Abbaszadegan et al., 2015). The surface zeta potential and size distribution were determined using DLS by using a laser particle sizer (Zetasizer Nano ZS, Malvern Instruments Ltd., Malvern, UK) at $25^{\circ} \mathrm{C}$ with a detection angle of $90^{\circ}$.

X-Ray Diffraction Analysis. X-Ray diffraction analysis is a common method to evaluate the crystal structure and atomic distance of AgNP. An X-ray diffractometer (Empyrean, PANalytical, Almelo, the Netherlands) was applied in this experiment with a radiation source of $\mathrm{CuKa}\left(\mathrm{k}=1.54 \mathrm{~A}^{\circ}\right.$; which is a characteristic fluorescent X-ray produced by highenergy electron bombardment of a copper target, with a specific wavelength of $1.54060 \AA$ ) and a programmable divergence slit. Parameters were set as follows: the voltage and current were $40 \mathrm{kV}$ and $20 \mathrm{~mA}$, respectively; the scanning angle $(2 \theta)$ was monitored from $10^{\circ}$ to $90^{\circ}$, and the scanning speed was set as $2.0^{\circ} / \mathrm{min}$ in a consecutive manner. The freeze-dried powder of AgNP was placed onto a silica plate and the EasySAXS software (PANalytical B. V., Almelo, the Netherlands) was applied to analyze the composition of elements. By comparing with the standard powder diffraction file of Ag (No. 04-0783; Supplemental Material S1, https:/ /doi.org/10.3168/jds.2018-15258), the possible crystal structure of AgNP was obtained.

FT-IR Spectroscopy Analysis. We used FT-IR to show the conjunction of surface functional groups, aiming to display interactions among chemical bonds during nucleation and growth of silver nanoparticles. The freeze-dried powder of AgNP was analyzed using an FT-IR spectrometer (Nicolet iS 50, Thermo Fisher Ltd., Waltham, MA), and the spectrum was collected at scanning scope from 4,500 to $450 \mathrm{~cm}^{-1}$ with a resolution of $1 \mathrm{~cm}^{-1}$. By deducting the background signal, the FT-IR spectrum was obtained.

\section{Antibacterial Tests of AgNP on C. sakazakii}

MIC Test. Five milliliters of sterilized LB liquid medium was aliquoted into sterile tubes $(10 \mathrm{~mL})$, followed by addition of $1 \mathrm{~mL}$ of each $C$. sakazakii strain adjusted to approximately $10^{8} \mathrm{cfu} / \mathrm{mL}$. The AgNP were added to make final concentrations from 1,000 to 7.81 $\mathrm{mg} / \mathrm{L}$ by 2 -gradient dilutions for each tube. Tubes with tested strains alone were used as positive controls, and tubes without the addition of $\mathrm{AgNP}$ and tested strains were negative controls. After incubation at $37^{\circ} \mathrm{C}$ for 12 $\mathrm{h}$ with shaking at $160 \mathrm{rpm}$, the survival of organisms was observed by visual inspection. Experiments were performed in triplicate and MIC was measured as the minimum concentration of $\mathrm{AgNP}$ resulting in no visible growth of bacteria.

Inhibition Zone Test. The Oxford cup method was applied to test the antibacterial activity of $\mathrm{AgNP}$ against $C$. sakazakii strains. The solid culture medium consisted of 2 layers: a water-agar layer of about 1 to $2 \mathrm{~mm}$ at the bottom with $1.5 \%$ (wt/vol) agar and a nutrient-agar layer about $2 \mathrm{~mm}$ at the top with $1 \%$ (wt/vol) agar. For each strain, $100 \mu \mathrm{L}$ of bacterial culture $\left(\sim 10^{8} \mathrm{cfu} / \mathrm{mL}\right)$ was spread on the plate followed by addition of $100 \mu \mathrm{L}$ of nanosilver suspensions with different concentrations to each hole after the Oxford cup was removed. Holes spotted with $5 \mathrm{mM} \mathrm{AgNO}_{3}$ solution and sterile water were used as positive and negative controls, respectively. After incubation at $37^{\circ} \mathrm{C}$ for $12 \mathrm{~h}$, inhibition zones were examined and their diameters measured to evaluate the antibacterial activity of AgNP. 


\section{Clarification of Potential Mechanism of AgNP Against C. sakazakii}

Observation of AgNP on the Cell Structure of C. sakazakii. A bacterial suspension of C. sakazakii ATCC $29544^{\mathrm{T}}$ was prepared by centrifuging $1 \mathrm{~mL}$ of cell culture $\left(\sim 10^{8} \mathrm{cfu} / \mathrm{mL}\right)$ at $5,000 \times g$ for $5 \mathrm{~min}$. The pellet was then rinsed and suspended in sterilized $0.85 \% \mathrm{NaCl}$. After treatment with AgNP at a final concentration of $200 \mathrm{mg} / \mathrm{L}$, the mix was incubated at $37^{\circ} \mathrm{C}$ for $2 \mathrm{~h}$ with shaking at $160 \mathrm{rpm}$. The cultures were centrifuged at $5,000 \times g$ for $5 \mathrm{~min}$ at room temperature to separate the bacteria and then observed using scanning electron microscopy (Hitachi S-3400N, Shimadzu Co. Ltd.) with an acceleration voltage of $5.0 \mathrm{kV}$. For scanning electron microscopy evaluation, the cell pellet was fixed using $2.5 \%$ ( $\mathrm{vol} / \mathrm{vol}$ ) glutaric dialdehyde for $2 \mathrm{~h}$ at $4^{\circ} \mathrm{C}$, rinsed with $0.1 M$ PBS, $\mathrm{pH} 6.8$, and subjected to gradient dehydration with 50, 70, 90, and 100\% (vol/vol) alcohol, each for 15 min. Pure tertiary butanol was added into the final mixture for $15 \mathrm{~min}$ to replace the alcohol, and the mixtures underwent freeze drying (ES-2030, Hitachi) for about $4 \mathrm{~h}$ to obtain solid samples in powder. Before observation, samples were transferred to a conductive adhesive upon the sample stage and surface-coated with a layer of platinum film

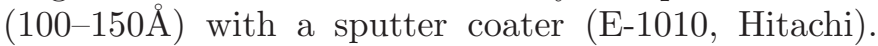
Cells without AgNP treatment were used as the negative control. Meanwhile, an energy-dispersive X-ray (EDX) fluorescence spectrometer (EDX-7000, Shimadzu Co. Ltd.) was used to determine whether AgNP were adsorbed to the surface of bacteria by determining characteristic X-ray signals and comparing them with that of elemental Ag.

Cellular Membrane Integrity Test. The LIVE/ DEAD BacLight Bacterial Viability Kit (L7007, Molecular Probes/Thermo Fisher Ltd.) was used to investigate changes in cell membrane integrity before and after addition of AgNP. Two nucleic acid stains, green-fluorescent SYTO 9 dye and red-fluorescent propidium iodide $(\mathbf{P I})$, were dissolved into $2.5 \mathrm{~mL}$ of sterile distilled water separately and mixed in darkness. Using C. sakazakii ATCC $29544^{\mathrm{T}}$ as the test strain, $1 \mathrm{~mL}$ of bacterial suspension $\left(\sim 10^{8} \mathrm{cfu} / \mathrm{mL}\right)$ was prepared. After incubation at $37^{\circ} \mathrm{C}$ for $2 \mathrm{~h}$ with shaking at $160 \mathrm{rpm}$, without or with the addition of $\mathrm{AgNP}$ at a final concentration of $200 \mathrm{mg} / \mathrm{L}, 100 \mu \mathrm{L}$ of each bacterial suspension was taken out and incubated with the prepared nucleic acid stains at a volume ratio of $1: 1$ for 10 min. Then, a laser scanning confocal microscope (LSCM, TCS SP2 AOBS, Leica, Wetzlar, Germany) was used to observe the fluorescent signal at excitation and emission wavelengths $(\mathbf{E x} / \mathbf{E m}=480 / 500 \mathrm{~nm}$ for
STYO9 green stain; $\mathrm{Ex} / \mathrm{Em}=535 / 615 \mathrm{~nm}$ for the PI red stain).

Determination of Cellular Membrane Potentials. To detect membrane potentials, a sensitive slowresponse membrane potential probe DiBAC4(3) [Bis(1,3- dibutyl barbituric acid) trimethine oxonol; Sigma, St. Louis, MO] was used. One milliliter of bacterial suspension $\left(\sim 10^{8} \mathrm{cfu} / \mathrm{mL}\right)$ of each $C$. sakazakii strain was prepared in $0.85 \% \mathrm{NaCl}$. Then, AgNP were added to test groups at a final concentration of $200 \mathrm{mg} / \mathrm{L}$ and treated for $2 \mathrm{~h}$; a control group had no AgNP added. Samples were collected by centrifugation at $6,000 \times g$ for $5 \mathrm{~min}$ and washed 3 times with $0.85 \% \mathrm{NaCl}$. One microliter per well of bacterial suspension was added to black poly-D-lysine 96 -well plates, followed by addition of $100 \mu \mathrm{L}$ of $1 \mu M$ DiBAC4(3) probe dissolved in dimethyl sulfoxide. Subsequently, the dye-loading plate was incubated in a cell incubator (250B type, Runhua Electric Appliance Co. Ltd., Jiangshu Sheng, China) at $37^{\circ} \mathrm{C}$ for $30 \mathrm{~min}$. A membrane potential assay was performed by monitoring fluorescence intensity at $\mathrm{Ex} /$ $\mathrm{Em}=493 / 516 \mathrm{~nm}$ by using a fluorescence microplate reader (SpectraMax iD3, Molecular Devices, San Jose, CA).

Determination of the Leakage of Reducing Sugars and Proteins. To detect the leakage of reducing sugars and proteins, 4 C. sakazakii strains (ATCC 29544 ${ }^{\mathrm{T}}$, ATCC BAA894, ATCC 29004, and ATCC 12868) were added separately into $10 \mathrm{~mL}$ of sterile LB culture with $\mathrm{AgNP}$ and incubated at $37^{\circ} \mathrm{C}$ with shaking at $160 \mathrm{rpm}$. The final concentration of $\mathrm{AgNP}$ was 200 $\mathrm{mg} / \mathrm{L}$ and the initial bacterial count of C. sakazakii was $10^{8} \mathrm{cfu} / \mathrm{mL}$. Cultures without AgNP were used as a control. One milliliter of each sample was collected after 0,1 , and $2 \mathrm{~h}$ and centrifuged at $12,000 \times g$ for 5 min. Supernatants were collected and stored at $-20^{\circ} \mathrm{C}$ immediately for subsequent analysis. Determination of the contents of reducing sugars and proteins was according to the methods of Miller (1959) and Sedmak and Grossberg (1977).

Detection of Intracellular ATP Levels. The ATP levels of each of the C. sakazakii strains before and after treatment with AgNP were measured by using a firefly luciferase-based ATP assay kit (Beyotime Bioengineering Institute, Shanghai, China) according to the manufacturer's instructions. After treatment with $\mathrm{AgNP}$ at a final concentration of $200 \mathrm{mg} / \mathrm{L}$ for 0 , 1, 2 and $4 \mathrm{~h}$, cells were collected, lysed, and centrifuged at $12,000 \times g$ for $5 \mathrm{~min}$. The initial bacterial number was about $10^{8} \mathrm{cfu} / \mathrm{mL}$. One hundred microliters of each supernatant was mixed with ATP detection working dilutions at a volume ratio of $1: 1$ in a black 96-well plate. The concentration of ATP was determined by 


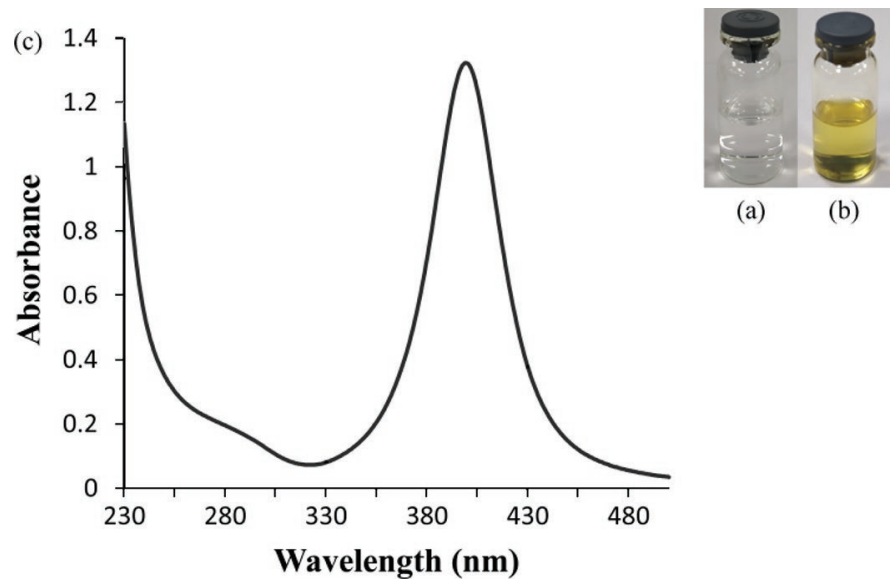

Figure 1. Visual appearance of (a) $\mathrm{AgNO}_{3}$ solution at a concentration of $5 \mathrm{~m} M$, and (b) synthesized silver nanoparticles by reducing $\mathrm{Ag}^{+}$; (c) UV-visible absorbance spectrum of silver nanoparticles. Color version available online.

using a luminometer (SpectraMax iD3, Molecular Devices) to determine relative light unit (RLU) values and calculated by generated standard curves. Assays were repeated in triplicate.

Assay for the Enzyme Activity of Respiratory Chain Dehydrogenases. To determine the enzyme activity of respiratory chain dehydrogenases before and after addition of AgNP, the iodonitrotetrazolium chloride (INT) method was used according to Li et al. (2010). Colorless INT can be reduced by dehydrogenases to a dark-red and water-insoluble iodonitrotetrazolium formazan (INF), which exhibits maximum absorbance at $490 \mathrm{~nm}\left(\mathrm{~A}_{490}\right)$. Thus, enzyme activity can be evaluated according to the spectrophotometric value of INF. One milliliter of bacterial suspension $(\sim 108 \mathrm{cfu} / \mathrm{mL})$ was added to $1.5-\mathrm{mL}$ sterile tubes, then divided into 3 experimental groups: (1) added $0.1 \mathrm{~mL}$ of 1,000 or 200 $\mathrm{mg} / \mathrm{L}$ of nanosilver suspensions to the test group; (2) supplied with $0.1 \mathrm{~mL}$ of PBS at $\mathrm{pH} 7.0$ to the positive control group; and (3) boiled for 20 min to inactivate dehydrogenases as the negative control group. Then all samples were co-incubated with $0.1 \mathrm{~mL}$ of $0.5 \%$ (wt/ wt) INT solution at $37^{\circ} \mathrm{C}$ for $2 \mathrm{~h}$. Subsequently, the INF was extracted with $1 \mathrm{~mL}$ of acetone/ethanol solution at a volume ratio of 1:1 and determined at wavelength of $490 \mathrm{~nm}$. The active unit (U) for enzymes was defined as the production of 1 micromole of INF per gram of dry cell weight in 1 minute and expressed as $\mu \mathrm{mol} /(\mathrm{g} \cdot \mathrm{min})$. The enzyme activity of dehydrogenases was calculated as follows:

$$
\text { Enzyme activity }=C_{I N F} \times \frac{V}{1,000} \times \frac{K}{B t},
$$

where $C_{I N F}$ is the molar concentration of INF $(\mu \mathrm{mol} / \mathrm{L})$ calculated from the generated standard curve of $\mathrm{A}_{490}$ versus $\mathrm{C}_{\mathrm{INF}} ; V$ is the sample volume $(\mathrm{mL})$ injected into each well of 96-well plate; $K$ is the dilution factor of INF extracting solutions; $B$ is the dry cell weight $(\mathrm{g})$, and $t$ is the reaction time (min).

\section{Statistical Analysis}

All experiments were conducted in triplicate; SPSS software (version 20.0; SPSS Inc./IBM Corp., Chicago, IL) was used to perform statistical analyses, and Origin software (version 2017; OriginLab Corp., Northampton, MA) was applied to construct curves. The data are reported as mean values \pm standard deviations $(n=3)$.

\section{RESULTS AND DISCUSSION}

\section{Characterization of AgNP}

UV-Visible Spectral Analysis. After reducing $\mathrm{Ag}^{+}$with citrate, the reaction mixture changed from colorless to a bright yellow color, indicating the formation of AgNP (Figure 1a, b). The SPR of silver nanoparticles showed an absorption peak at $405 \mathrm{~nm}$ (Figure 1c), which was within the specific absorption range of spherical silver nanoparticles. The results also revealed a narrow FWHM value of $42 \mathrm{~nm}$ (Figure 1c), showing that nanoparticles were uniform in size.

Morphology and Size Distribution Analysis of $\boldsymbol{A g N P}$. The TEM results showed that the synthesized AgNP were spherical with a primary size distribution from 20 to $40 \mathrm{~nm}$, which occupied over $70 \%$ of the total range (Figure 2a, b, and c). No aggregation of nanoparticles was observed. Meanwhile, the hydrodynamic diameter and dispersity of the AgNP were analyzed by the DLS method (Table 1). The DLS results showed the mean size of AgNP was $46.5 \mathrm{~nm}$, slightly larger than the physical diameter of $31.2 \mathrm{~nm}$ as determined by TEM. As a weighted-average measurement, DLS is biased toward larger particle sizes and especially toward agglomerates and aggregates. The polydispersity index value was 0.292 , suggesting a uniform dispersity of AgNP.

$\boldsymbol{X} \boldsymbol{R} \boldsymbol{D}$ Analysis. X-Ray diffraction of $\mathrm{AgNP}$ is shown in Figure 3, with 4 diffraction peaks (at $2 \theta$ degrees) of 38.071, 44.226, 64.445, and 77.348. According to the standard powder diffraction card of silver file no. 04-0783 published by the Joint Committee on Powder Diffraction Standards (JCPDS; Supplemental Material S1, https://doi.org/10.3168/jds.2018-15258), the 4 diffraction peaks correspond to the (111), (200), (220), and (311) planes of face-centered cubic (fcc) silver. 

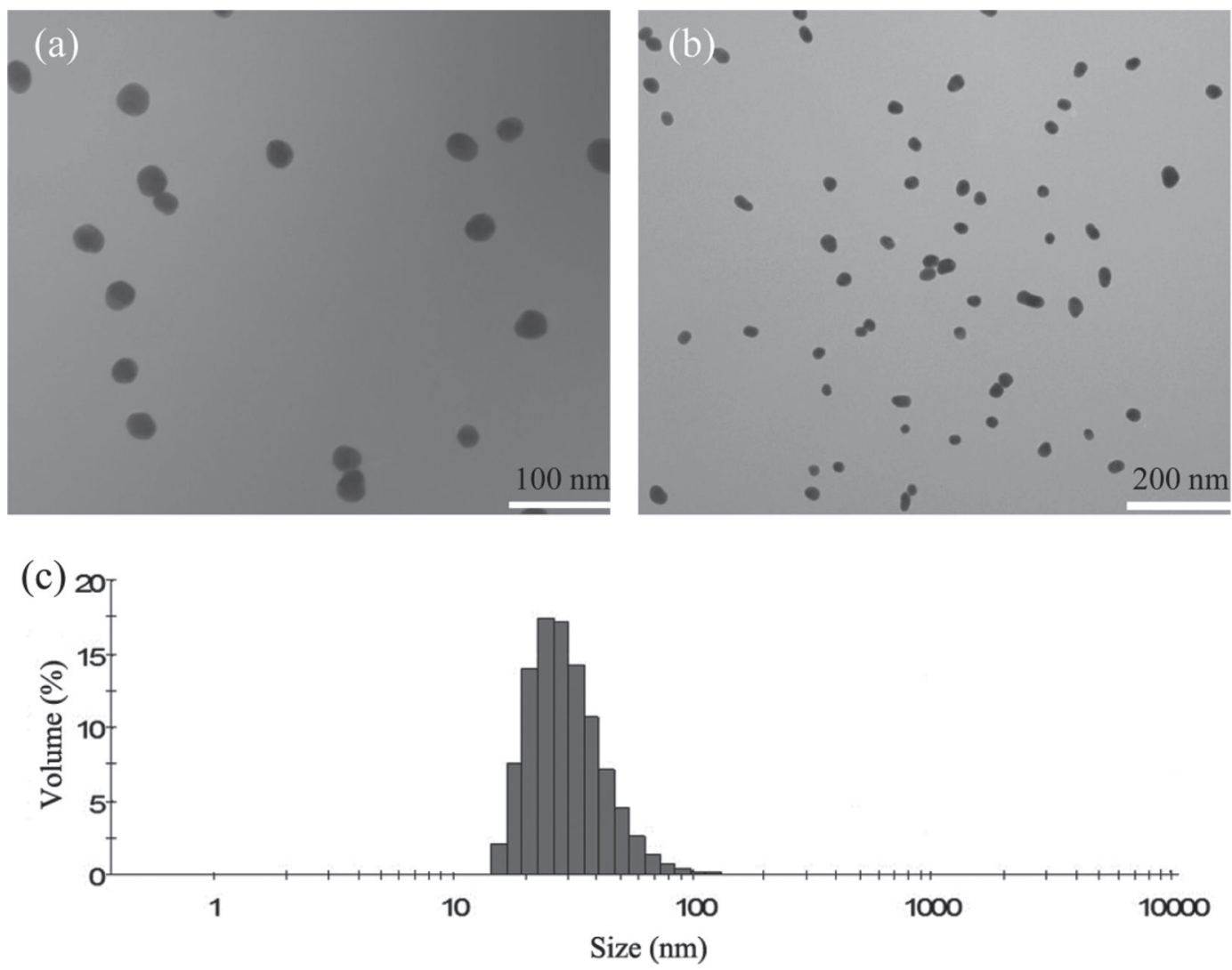

Figure 2. Transmission electron microscopy images of silver nanoparticles (AgNP) at (a) 200,000× (scale bar $=100 \mathrm{~nm})$ and $(\mathrm{b}) 100,000 \times$ $($ scale bar $=200 \mathrm{~nm})$; and $(\mathrm{c})$ size distribution of AgNP by random statistics of 1,000 sample points from 10 visual fields, each field having 100 sample spots.

Thus, the crystal structure of silver nanoparticles was essentially in the fcc pattern and crystallized in nature.

$\boldsymbol{F T - I R}$ Spectrum of AgNP. The FT-IR spectrum of silver nanoparticles is displayed in Figure 4, showing 11 peaks at positions $3403.29,2921.59,2320.81,1626.27$, $1341.01,1137.05,1050.43,995.95,925.47,867.74$, and $591.66 \mathrm{~cm}^{-1}$. The strong absorbance band at 3403.29 $\mathrm{cm}^{-1}$ is related to $\mathrm{O}-\mathrm{H}$ stretching vibrations of glycerol and sucrose (Noh et al., 2012). The peak at 2921.59 $\mathrm{cm}^{-1}$ is assigned to $\mathrm{C}-\mathrm{H}$ stretching vibration and $\mathrm{CH}_{2}$ bending vibration (Devaraj et al., 2013). The band at $2320.81 \mathrm{~cm}^{-1}$ attributed to the conjugated double bond of $\mathrm{O}=\mathrm{C}-\mathrm{C}-\mathrm{C}=\mathrm{O}$ originating from the oxidation of citrate. The characteristic amide $(\mathrm{NH})-\mathrm{C}=\mathrm{O}$ and $\mathrm{C}=\mathrm{C}$ stretching vibration was observed at $1626.27 \mathrm{~cm}^{-1}$ whereas N-H stretch was at wavenumber $1341.01 \mathrm{~cm}^{-1}$ (Noh et al., 2012). This result showed the involvement in AgNP of nitrogen atoms, which might have originated from the dispersant PVP used in the preparation process. The bands at $1137.05,1050.43$, and $995.95 \mathrm{~cm}^{-1}$ were assigned to the stretching vibrations of primary amine $\mathrm{C}-\mathrm{N}$ and $\mathrm{C}-\mathrm{C}$ (Jyoti et al., 2016; El-Naggar et al., 2017). These bands were shifted to a lower wavenumber at $925.47 \mathrm{~cm}^{-1}$ due to the spatial resistance of AgNP. The peaks at $867.74 \mathrm{~cm}^{-1}$ and $591.66 \mathrm{~cm}^{-1}$ were related to $\mathrm{C}=\mathrm{CH}_{2}$ and $-\mathrm{C}-\mathrm{CN}$ stretching vibrations, respectively (Dauthal and Mukhopadhyay, 2013). As a result, most functional groups belonging to citrate and

Table 1. Comparative analysis of the size and polydispersity of silver nanoparticles determined by dynamic light scattering (DLS) and transmission electron microscopy (TEM)

\begin{tabular}{llccc}
\hline $\begin{array}{l}\text { Detection } \\
\text { method }\end{array}$ & $\begin{array}{l}\text { Temperature } \\
\left({ }^{\circ} \mathrm{C}\right)\end{array}$ & $\begin{array}{c}\text { Mean particle } \\
\text { size }(\mathrm{nm})\end{array}$ & PDI $^{1}$ & $\begin{array}{c}\text { Scanning } \\
\text { angle }\left({ }^{\circ}\right)\end{array}$ \\
\hline DLS & 25 & 46.5 & 0.292 & 90 \\
TEM & 37 & 31.2 & - & - \\
\hline
\end{tabular}

${ }^{1}$ Polydispersity index. 
its degradation products were involved in the synthesis of AgNP and surrounded with a silver nucleus $\left(\mathrm{Ag}^{0}\right)$. Silver nanoparticles may conjunct with PVP to prevent agglomeration in the preparation process.

Surface Zeta Potential of AgNP. The surface zeta potential results are shown in Figure 5, revealing a mean zeta potential of $+18.7 \mathrm{mV}$ (SD: $3.18 \mathrm{mV}$ ) with a mean conductivity of $0.0153 \mathrm{mS} / \mathrm{cm}$. Thus, the surface of AgNP was capped with a cation layer resulting in a positive charge, which may result from embedded $\left[\mathrm{NH}_{4}\right]^{+}$in the reaction system.

\section{Antibacterial Activity of AgNP Against C. sakazakii}

MIC of AgNP on C. sakazakii. Silver nanoparticles exhibited strain-specific variation in antibacterial activity against 4 C. sakazakii strains. For ATCC $29544^{\mathrm{T}}$ and ATCC BAA894, the MIC was $125 \mathrm{mg} / \mathrm{L}$ AgNP, whereas for ATCC 20994 and ATCC 12868, the MIC was $62.5 \mathrm{mg} / \mathrm{L}$ (Table 2).

Diameters of Inhibition Zone. Silver nanoparticles can inhibit the growth of surrounding bacteria to form an aseptic area when added to LB agar medium. Mean diameters of inhibition zones for ATCC 12868, ATCC 29004, ATCC 29544, and ATCC BAA894 in the
AgNP treatment group were 16, 16.3, 14.3, and 13.8 $\mathrm{mm}$ (Figure 6), greater than that of $\mathrm{Ag}^{+}$group (mean diameters of 11.8, 12.8, 13.3 and $12 \mathrm{~mm}$, respectively). Silver nanoparticles showed stronger antibacterial activity than $\mathrm{Ag}^{+}$against all 4 strains of $C$. sakazakii. The blank group showed no antibacterial activity, and the inhibition zone values were displayed as the external diameter of the Oxford cup.

\section{Potential Antibacterial Mechanism of AgNP on C. sakazakii}

Changes in Cell Structure by Scanning Electron Microscopy. Scanning electron micrographs showed that the morphology of $C$. sakazakii in a normal state was full, rod-shaped with a wrinkled superficial surface (Figure 7c), whereas strains treated with AgNP showed adsorption of particles (Figure 7a) and bacterial cell disruption (Figure 7b). To further confirm the elemental component of adsorbed particles, EDX analysis was applied and the spectrum is displayed in Figure 7d. The EDX spectrum showed a typical optical observation peak at near $3 \mathrm{keV}$ due to SPR, confirming the presence of silver and adsorption of crystal AgNP.

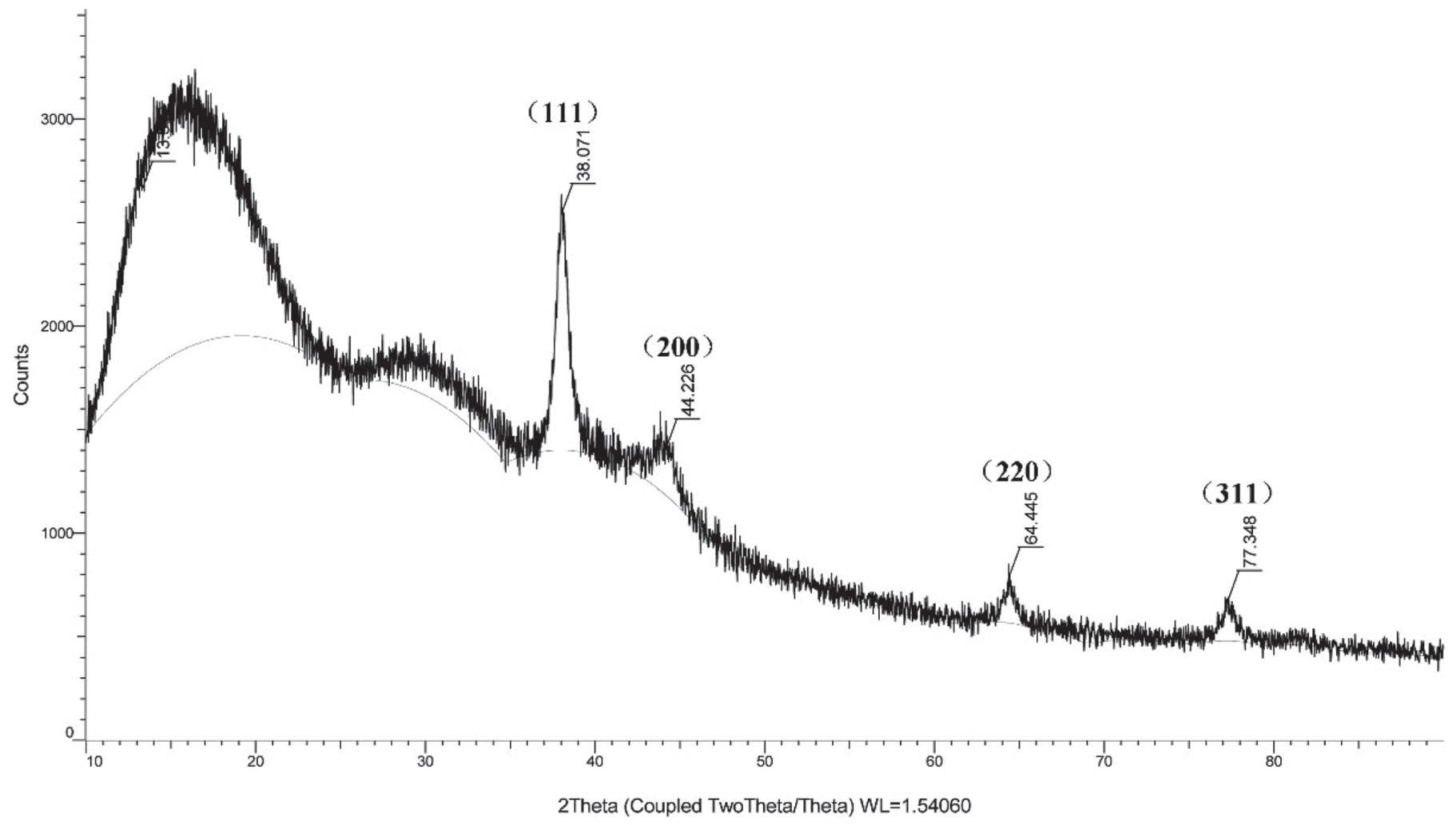

Figure 3. X-Ray diffraction of silver nanoparticles synthesized by sodium citrate. 2 theta $(2 \theta)=$ the diffraction angle of characteristic X-ray; $\mathrm{WL}=$ wavelength. Four characteristic peaks of $2 \theta$ at 38.071, 44.226, 64.445, and 77.348 were displayed, corresponding to the (111), (200), (220) and (311) planes, inserted on the peak numbers separately of crystal silver according to the standard powder diffraction file No. 04-0783. 
Cellular Membrane Integrity Injury. In this test, green-fluorescent SYTO 9 dye $(\mathrm{Ex} / \mathrm{Em}=480 / 500$ $\mathrm{nm})$ can pass through intact cell membranes and fluoresce bright green, whereas bacteria with damaged membranes show a reduction in green fluorescence or fluoresce red because of the red-fluorescing PI (Ex/Em $=535 / 615 \mathrm{~nm}$ ). Laser scanning confocal micrographs of untreated bacteria showed bright green fluorescence with no red signal (Figure 8a), indicating that the cellular membrane was intact. However, after treatment with AgNP for $2 \mathrm{~h}$ at a final concentration of 200 $\mathrm{mg} / \mathrm{L}$, strong red fluorescence was observed in partial bacterial cells (Figure 8b), indicating loss of cellular membrane integrity. The mechanism of cell membrane damage and subsequent cell damage requires further investigation.

Membrane Potential. Changes in plasma membrane potentials, shown in Figure 9, were determined by using the slow-response potential-sensitive probe DiBAC4(3). Bacterial cells of C. sakazakii strains treated with AgNP showed a noticeable decrease in fluorescence, demonstrating hyperpolarization of the cell membrane. This result suggests that AgNP may have damaged cell membrane integrity by inducing cell membrane hyperpolarization at an early stage.

Leakage of Intracellular Reducing Sugars and Proteins. The standard curves for determination of the contents of reducing sugars and proteins were $\mathrm{Y}=$ 1.746X - 0.0054 $\left(R^{2}=0.9996\right.$, shown in Supplemental
Figure S1; https://doi.org/10.3168/jds.2018-15258) and $\mathrm{y}=6.9943 \mathrm{x}+0.0031\left(\mathrm{R}^{2}=0.9991\right.$, shown in Supplemental Figure S2; https://doi.org/10.3168/jds .2018-15258) respectively, where $\mathrm{Y}$ and y represented absorbance at 540 and $595 \mathrm{~nm}$, respectively, and $\mathrm{X}$ and $\mathrm{x}$ represent the contents of standard solutions of glucose and BSA, respectively. Figure 10 shows the contents of reducing sugars and proteins in supernatants of bacterial cultures with or without AgNP treatment. For C. sakazakii ATCC $29544^{\mathrm{T}}$, the amounts of leaked reducing sugars and proteins increased from 11.4 (at $0 \mathrm{~h}$ ) to 172.5 (at $2 \mathrm{~h}$ ) $\mu \mathrm{g} / \mathrm{mg}$ of bacterial dry weight for sugars and 7.8 (at $0 \mathrm{~h}$ ) to 14.6 (at $2 \mathrm{~h}) \mu \mathrm{g} / \mathrm{mg}$ of bacterial dry weight for proteins (Figure 10a). Similar results were obtained for ATCC BAA894 (Figure 10b), ATCC 29004 (Figure 10c), and ATCC 12868 (Figure 10d), indicating that AgNP accelerated the leakage of reducing sugars and proteins from the cytoplasm through damage and disruption of the cell membrane. However, bacterial cells of the control group exhibited a slight increase in reducing sugars and proteins contents that were secreted by cells during incubation.

Intracellular ATP Concentrations. Adenosine triphosphate is an important energy resource that participates in various physiological activities of bacterial cells. Changes in intracellular ATP concentrations in bacterial cells of each of the C. sakazakii strains before and after addition of AgNP are shown in Figure 11. The ATP levels in untreated bacterial cells of ATCC

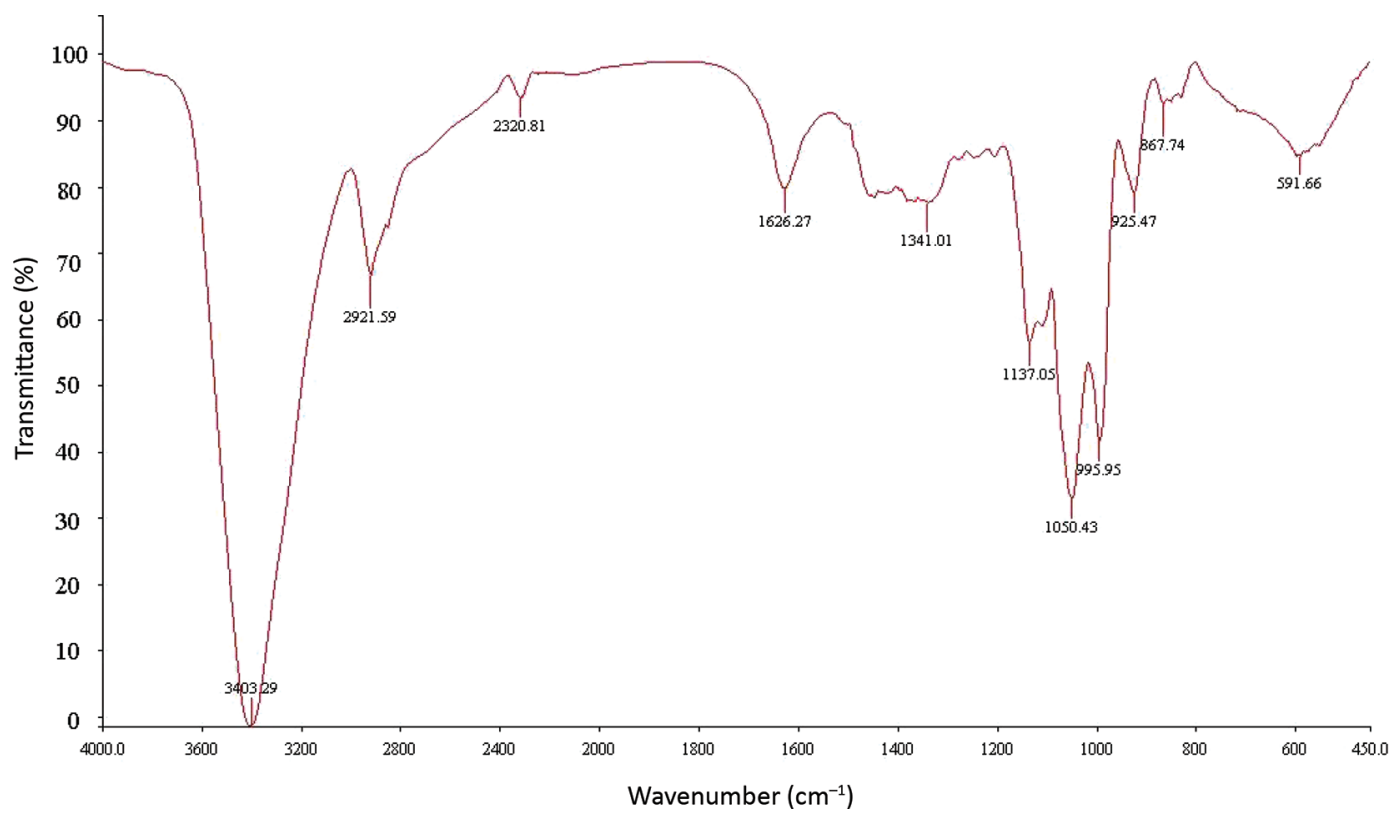

Figure 4. Fourier transform infrared spectroscopy of silver nanoparticles synthesized with sodium citrate. The x-axis indicates the wavenum-

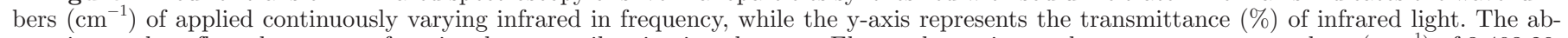

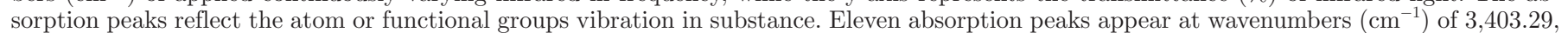

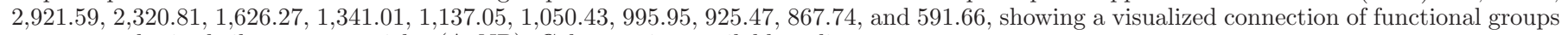
among synthesized silver nanoparticles (AgNP). Color version available online. 


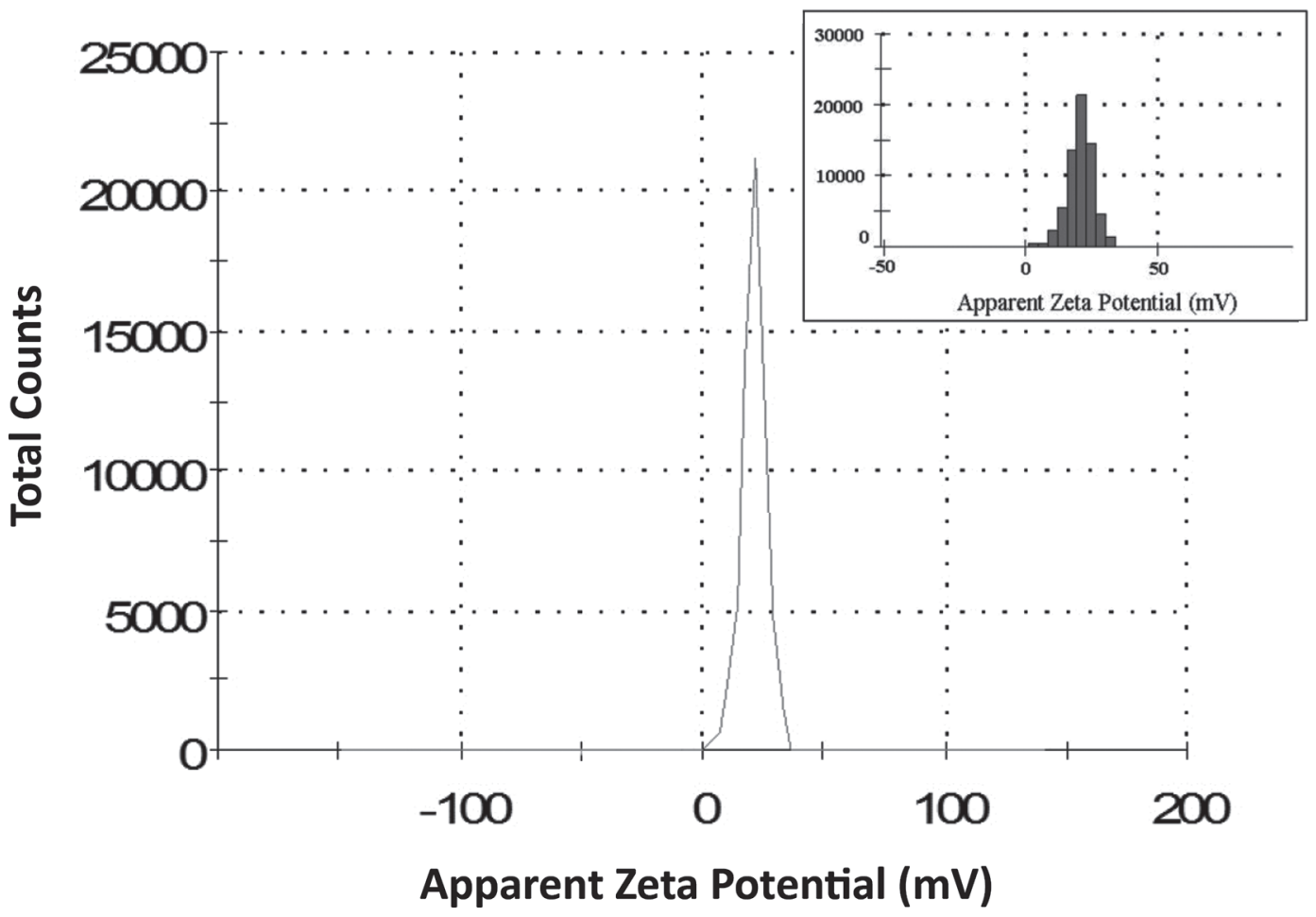

Figure 5. Apparent zeta potential of silver nanoparticles with a positive zeta value synthesized by sodium citrate at $\mathrm{pH}$. The inset figure shows a corresponding histogram of apparent zeta potential $(\mathrm{mV})$ of silver nanoparticles (AgNP) versus total counts, which gives a direct description about primary zeta potential distribution around 10 to $25 \mathrm{mV}$.

$29544^{\mathrm{T}}$, ATCC BAA894, ATCC 29004, and ATCC 12868 were $8.51,4.11,4.087$, and $5.457 \mu M$ respectively, and these values dramatically decreased $(P<0.05)$ to $0.019,0.37,0.125$, and $0.102 \mu M$ after $1 \mathrm{~h}$ of treatment with AgNP. Reduction of intracellular ATP levels usually occurs with associated impairment or dysfunction of respiratory chain enzymatic activity.

Enzyme Activity of Respiratory Chain Dehydrogenases. The effect of AgNP on the enzyme activity of respiratory chain dehydrogenases of the $4 C$. sakazakii strains is shown in Figure 12. For C. sakazakii ATCC $29544^{\mathrm{T}}$, the activity of dehydrogenases in the positive control bacterial cells fluctuated around 150 $\mu \mathrm{mol} /(\mathrm{g} \cdot \mathrm{min})$, whereas dehydrogenases in the negative control cells (boiled for $20 \mathrm{~min}$ ) showed nearly no activity (Figure 12a). Interestingly, the enzyme activity of bacterial cells increased temporarily during the first 15 min of treatment with the lower concentration of AgNP. A similar phenomenon was observed for ATCC BAA894 (Figure 12b). However, the activity

Table 2. Minimum inhibitory concentrations $(\mathrm{mg} / \mathrm{L})$ of silver nanoparticles (AgNP) and growth (negative or positive) of different strains of Cronobacter sakazakii

\begin{tabular}{|c|c|c|c|c|c|}
\hline Dilution & $\begin{array}{l}\mathrm{AgNP} \\
(\mathrm{mg} / \mathrm{L})\end{array}$ & \multicolumn{4}{|c|}{ C. sakazakii strain } \\
\hline 1 & 1,000 & - & - & - & - \\
\hline 3 & 250 & - & - & - & - \\
\hline 4 & 125 & - & - & - & - \\
\hline 5 & 62.5 & + & - & - & + \\
\hline 8 & 7.81 & + & + & + & + \\
\hline Control $(-)^{1}$ & & - & - & - & - \\
\hline Control $(+)^{2}$ & & + & + & + & + \\
\hline
\end{tabular}

${ }^{1}$ Control $(-)=$ control group without addition of AgNP and tested C. sakazakii strains.

${ }^{2}$ Control $(+)=$ control group with tested strains but no AgNP. 
of dehydrogenases decreased rapidly with increasing incubating time after AgNP treatment of ATCC 29004 (Figure 12c) and ATCC 12868 (Figure 12d). The results showed that AgNP could efficiently inhibit the activity of respiratory chain dehydrogenases; a higher concentration of AgNP was associated with a stronger inhibitory activity.

\section{General Discussion}

In this study, AgNP were synthesized by the chemical reduction method using citrate as reducing reagent and glycerol and PVP as stabilizers. The chemical reducing method is usually used to prepare AgNP; reaction temperature, $\mathrm{pH}$, and molar ratio of $\mathrm{Ag}^{+}$and reducer are 3 critical influencing factors (Lee et al., 2004; Dong et al., 2009). High temperature speeds up the reducing reaction, forming a certain amount of silver nuclei in a short period, and accelerates Brownian movement to enhance opportunities for conjunction with silver nanoparticles (Kreibig, 2001). The pH value is consistent with the $\mathrm{pH}$-dependent reducing activity of citrate, with higher $\mathrm{pH}$ conditions of reaction systems showing a fast nucleation process (Ji et al., 2007). Dong et al. (2009) proposed a stepwise reduction method in which nucleation and growth processes were performed at high and low $\mathrm{pH}$, respectively, to synthesize a spherical AgNP. The molar ratio of $\mathrm{Ag}^{+}$and reducer affects the amount of silver nuclei and subsequently controls the concentration and shape of prepared AgNP. Moreover, dispersants are essential for the reaction system of the chemical reduction method; PVP is commonly used as a non-ionic polymer by compounding with $\mathrm{Ag}$ to pro-

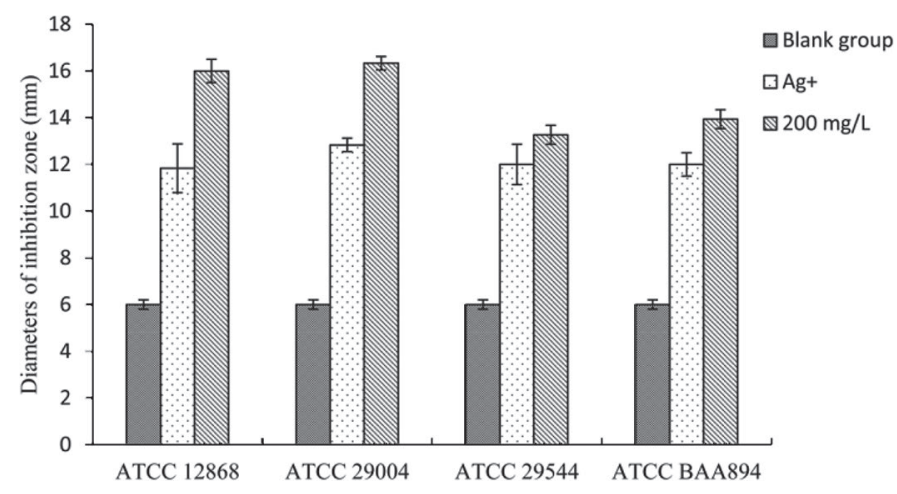

Figure 6. Diameters of inhibition zone of $\mathrm{Ag}+$ and silver nanoparticles against Cronobacter sakazakii strains. The blank group represents the external diameter of the Oxford cup with no formation of inhibition zone. The $\mathrm{Ag}+$ or $200 \mathrm{mg} / \mathrm{L}$ group was treated by spotting $100 \mu \mathrm{L}$ of $5 \mathrm{mM} \mathrm{AgNO}_{3}$ solution or $200 \mathrm{mg} / \mathrm{L}$ of nanosilver suspensions separately into nutrient-agar plates, which were spread with 100 $\mu \mathrm{L}(\sim 108 \mathrm{cfu} / \mathrm{mL})$ of bacterial cultures of 4 different species in advance. The diameters of inhibition zone are displayed as mean \pm SD of data collected from 3 repeated experiments. tect the AgNP from growing and agglomerating (Wang et al., 2005).

The antibacterial activity of AgNP depends on the size and shape of nanoparticles, with a smaller size and presence of the (111) plane enhancing biocidal property against Escherichia coli (Pal et al., 2007; Carlson et al., 2008; Raza et al., 2016). Meanwhile, the surface charge of silver nanoparticles is related to the action of adsorption to the cell membrane at early stages by electrostatic interaction (El Badawy et al., 2011). Thus, it is important to characterize AgNP in terms of their surface topography, size distribution, crystal structure, connection of surface functional group, and surface charge condition. In this study, the synthesized AgNP were spherical with a mean particle size of 31.2 $\mathrm{nm}$, similar to the results of Ranoszek-Soliwoda et al. (2017) but with a narrower size distribution due to the reducing capacity of both citrate and glycerol in boiling systems. The zeta potential was $+18.7 \mathrm{mV}$, carrying the opposite charge to certain silver nanoparticles prepared by bio-fabrication, for example, using a proteinaceous pigment phycocyanin extracted from Nostoc linckia as the reducing reagent (El-Naggar et al., 2017). Meanwhile, the AgNP in the current study proved to be stable in aqueous solution with such zeta potential due to sufficient electrostatic repulsion. In addition, after freeze-drying, we determined an fcc crystal structure of AgNP, and this crystal structure is common to spherical silver nanoparticle powders, as reported by Naik et al. (2002) and Majeed Khan et al. (2011), prepared by in vitro biosynthesis using silver-binding peptides and wet chemical solution method by reducing $\mathrm{Ag}^{+}$with glucose in alkaline conditions, respectively.

The cell envelope of C. sakazakii, a gram-negative bacterium, consists of 2 membranes, with the outer membrane providing the outermost cell barrier and the cytoplasmic membrane serving as an electrochemical barrier and maintaining metabolism and energy transduction (Schwechheimer and Kuehn, 2015). It is important for bacterial cells to maintain the integrity of their cell membrane to perform material transportation and energy metabolism. Damage of the cell membrane is usually accompanied by (1) increasing membrane permeability, causing leakage of intracellular substances such as reducing sugars and proteins; (2) changes in membrane potentials; and (3) decreases in intracellular ATP due to diminishing proton motive force. In previous studies, Raffi et al. (2008) reported that AgNP adhered to and penetrated bacterial cells after interaction with Escherichia coli; similar results published by Li et al. (2010) showed that AgNP caused damage and fragmentation of the cell membrane of $E$. coli. In the current study, adsorption of AgNP on the surface of $C$. sakazakii bacterial cell and subsequent cell membrane 
damage was observed by scanning electron microscopy after treatment with AgNP. Moreover, accelerated leakage of intracellular reducing sugars and proteins existed in treated bacterial cells in the current study, suggesting that AgNP either affected cell membrane integrity or increased membrane permeability to produce antibacterial activity against C. sakazakii. However, in the current study, we focused on the binding of
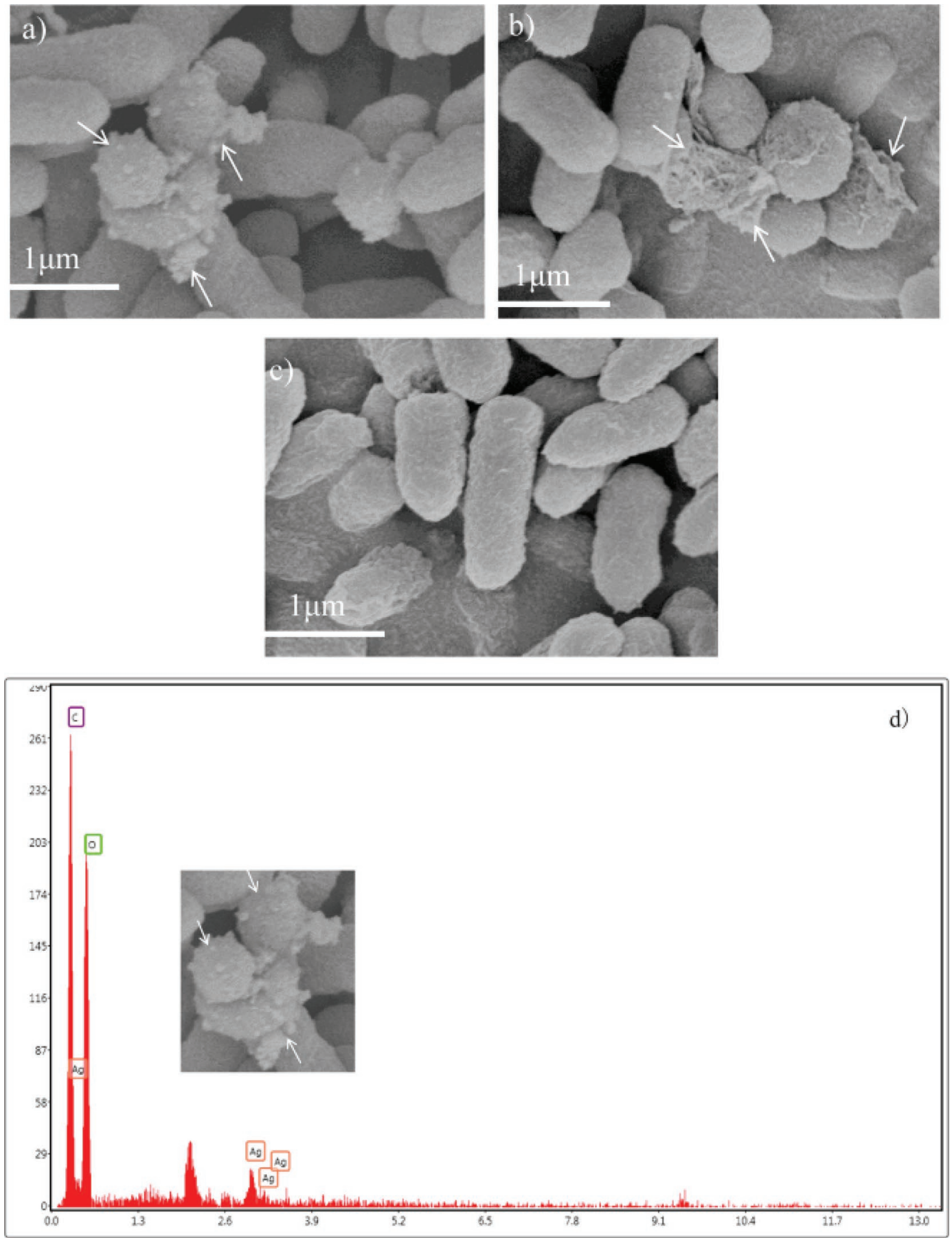

Figure 7. Scanning electron microscopy of Cronobacter sakazakii ATCC $29544^{\mathrm{T}}$ treated with silver nanoparticles (a, b) and untreated (c). Panel a shows the adsorption of particles on the surface of bacteria, whereas panel b displays cell disruption of partial bacteria. The full, rodshaped cell morphology with a wrinkled superficial surface was observed for untreated bacteria in panel c. The magnification is $35,000 \times$ at a voltage of $5.0 \mathrm{kV}$. (d) Energy-dispersive X-ray spectrum of particles adhered to the surface of cell membrane, which proved the existence of elemental silver. Color version available online. 


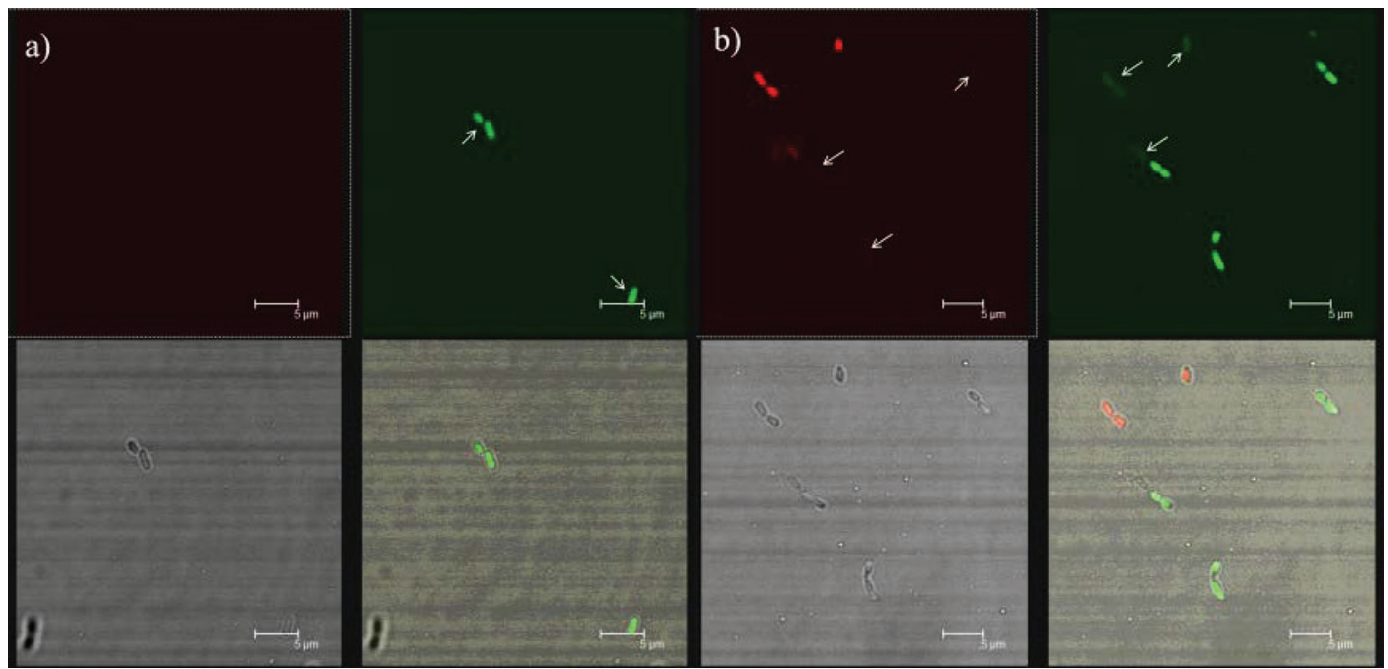

Figure 8. Images of Cronobacter sakazakii ATCC $29544^{\mathrm{T}}$ before (a) and after (b) addition of silver nanoparticles determined by laser scanning confocal microscopy. Green fluorescence excited by SYTO 9 dye at a wavelength of $480 \mathrm{~nm}$ represents the bacteria with intact cell membrane, whereas red fluorescence generated by propidium iodide (PI) at a wavelength of $535 \mathrm{~nm}$ represents bacteria with damaged cell membrane integrity. The length of scale bars is $5 \mu \mathrm{m}$. Color version available online.

nanoparticles onto cells and sugar and protein leakage and did not specifically measure membrane integrity or permeability. This is a limitation of the present study that could be rectified by using methods such as liquid chromatography (LC)-MS or LC-tandem MS (LC-MSMS) based on van Breemen and $\mathrm{Li}$ (2005). In future studies, LC-MS and LC-MS-MS methods could provide a more sensitive and selective analysis of the concentrations of sugars and proteins on either side of the bacterial cell compared with the spectrophotometric method applied here, which was based on characteristic absorption of synthesized color compounds. Thus, we were

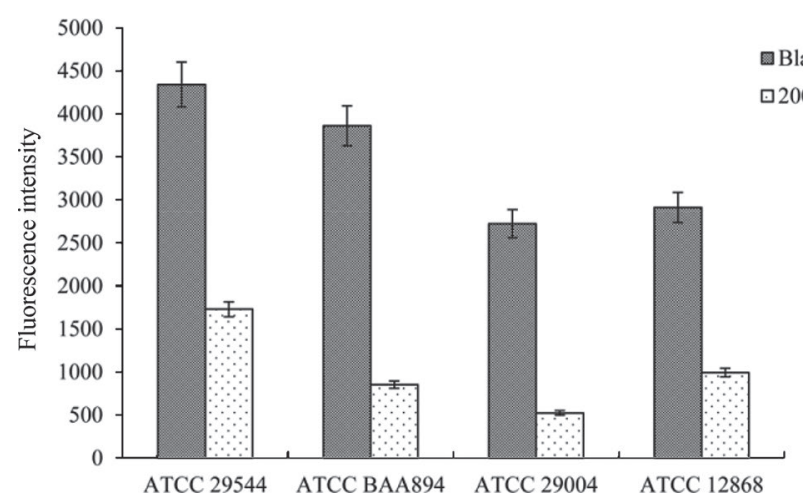

Figure 9. Changes in membrane potential of 4 Cronobacter sakazakii strains untreated (blank) or treated with $200 \mathrm{mg} / \mathrm{L}$ silver nanoparticles for $2 \mathrm{~h}$. Cells of both the blank group and treatment group were collected separately by centrifugation at $6,000 \times g$ for $5 \mathrm{~min}$ and co-incubated with $\mathrm{DiBAC}_{4(3)}$ at $37^{\circ} \mathrm{C}$ for $30 \mathrm{~min}$. The fluorescence intensity was determined by using a fluorescence microplate reader at wavelength of excitation/emission $=493 / 516 \mathrm{~nm}$. Error bars display the SD of data collected from 3 repeated experiments. able to know, before and after treatment with AgNP, which components were acceleratedly effluxed out from cells due to changes of cell membrane in integrity or permeability. Additional studies should focus on components of intracellular and extracellular oligo- or polysaccharides such as trehalose, a disaccharide inside the cell that contributes to the desiccation adaptation of Cronobacter spp., and capsular polysaccharides located on the cell surface that play a pivotal role in biofilm formation (Lehner et al., 2005; Jaradat et al., 2014). In addition, it would be interesting to identify proteins unique to C. sakazakii strains, such as those involved in pilus assembly and toxin/antitoxin systems, or as a function of phosphotransferase, sialic acid transporter, and $N$-acetylneuraminate lyase (Kucerova et al., 2010).

To detect membrane potential, we used DiBAC4(3), a sensitive slow-response probe that can pass through the cellular membrane freely to maintain a dynamic balance between the internal and external charges due to its lipophilic anionic properties. Membrane hyperpolarization resulted from a decrease in the membrane potential. Hyperpolarization of the membrane has been reported as a characteristic phenomenon of cell membrane damage according to research with Pseudomonas huttiensis strain D1 as described by Yuroff et al. (2003). Meanwhile, research on the mode of action of membrane hyperpolarization by Bot and Prodan (2009) found that increased $\mathrm{K}^{+}$pumped from the cell membrane $\mathrm{K}^{+}$channels decreased membrane potential in E. coli. Similar results were observed in Staphylococcus aureus, in which $\mathrm{K}^{+}$was released from bacterial cells in a dose-dependent manner after treatment with shikimic 
acid, an important antibacterial organic acid. Increased $\mathrm{K}^{+}$efflux leads to the changes of membrane permeability and membrane damage; as a result, some contents of bacterial cells including ions, nucleotides, sugars, and proteins can leak (Bot and Prodan, 2009; Bai et al., 2015). In the present study, membrane potentials of all 4 C. sakazakii strains decreased following treatment with AgNP, suggesting that AgNP hyperpolarized the bacterial cell membrane and affected cellular homeostasis. However, further study is required to elucidate whether $\mathrm{K}^{+}$efflux occurred in C. sakazakii cells when treated with AgNP.

Adenosine triphosphate is an important energy resource, participating in various physiological activities of bacterial cells. Changes in intracellular ATP levels usually accompany dysfunction of the respiratory chain and cell death (Johler et al., 2010). Bragg and Rainnie (1974) reported that silver ions inhibited the oxidation
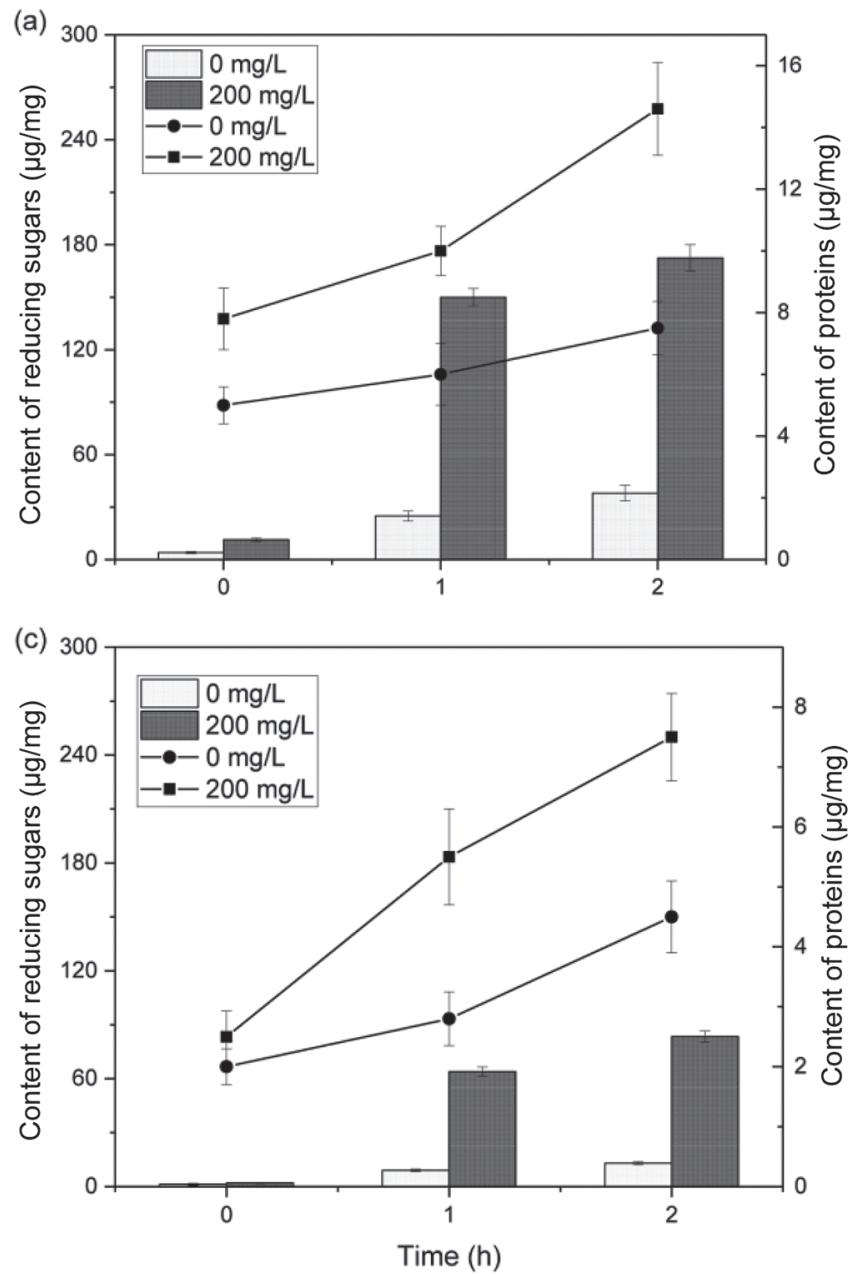

of endogenous substrates by reacting with the respiratory chain at 2 sites in E. coli: one was located between the $b$-cytochromes and cytochrome $a_{2}$, and the other in the NADH and succinate dehydrogenase regions. Another report showed that low concentrations of $\mathrm{Ag}^{+}$ induced massive proton leakage through the membrane of Vibrio cholerae, causing a dramatic reduction in ATP levels and resulting in cell death (Dibrov et al., 2002). Li et al. (2011) reported on the antibacterial activity of silver nanoparticles on Staphylococcus aureus ATCC $6538 \mathrm{P}$ and the results showed that AgNP reduced the enzymatic activity of respiratory chain dehydrogenases and decreased intracellular ATP levels. In this study, reduction of ATP levels and inhibition of respiratory chain dehydrogenases were observed after treatment with AgNP. Interestingly, a temporary increase in enzymatic activity of dehydrogenases was detected in C. sakazakii ATCC $29544^{\mathrm{T}}$ and ATCC BAA894, which
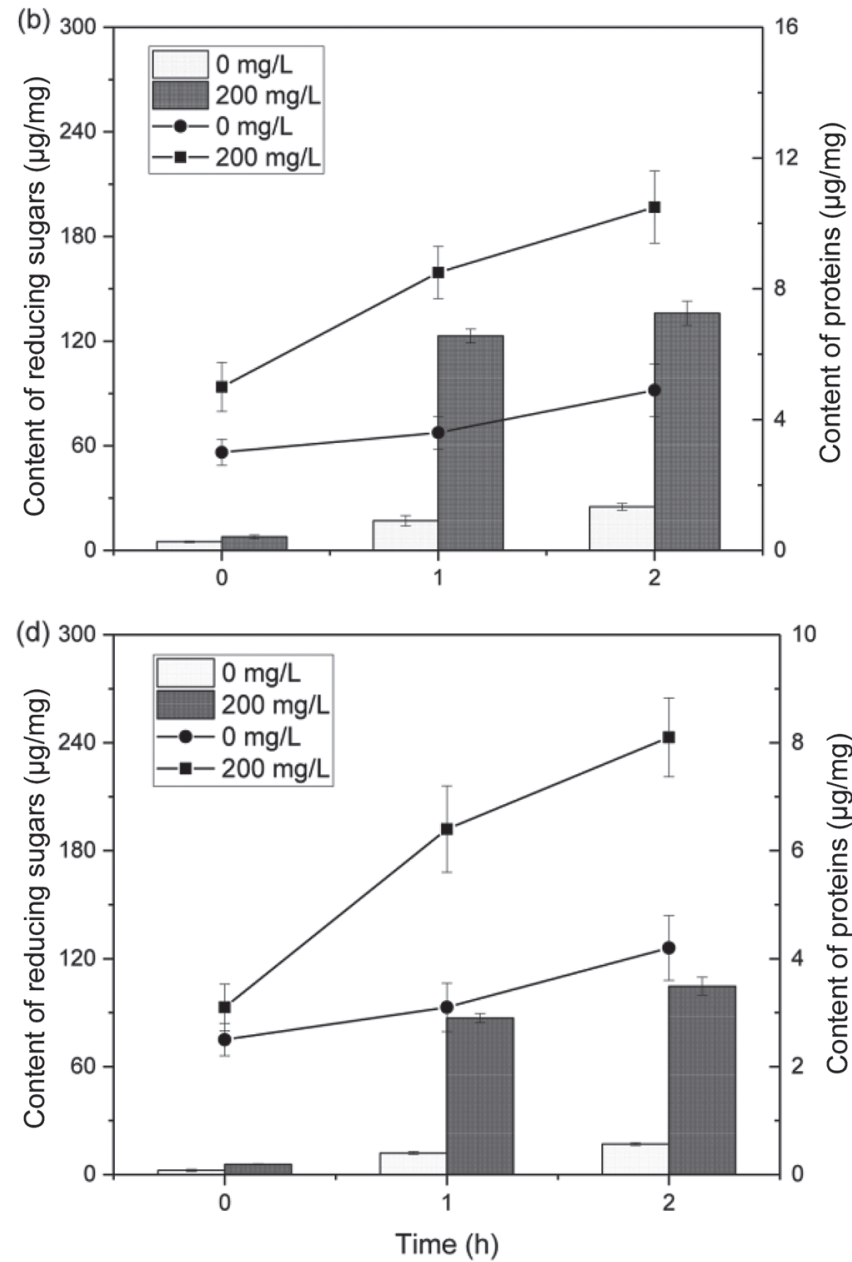

Figure 10. Leakage of reducing sugars (bars) and proteins (- - ) for 4 Cronobacter sakazakii strains without $(0 \mathrm{mg} / \mathrm{L})$ or with treatment of silver nanoparticles at a final concentration of $200 \mathrm{mg} / \mathrm{L}$ : (a) ATCC 29544 ${ }^{\mathrm{T}}$, (b) ATCC BAA894, (c) ATCC 29004 , and (d) ATCC 12868. Error bars represent the SD of data from 3 repetitive experiments. 
could imply resistance to stress with treatment at a lower concentrations of AgNP. However, this hypothesis should be verified in further experiments by combined transcriptomic and proteomic analysis to identify genes and proteins that might be involved in this finding.

To date, nano-Ag is used frequently and is found in $25 \%$ of nano-enabled products (Vance et al., 2015). The major application is as protection against fungi, virus, and bacteria, especially some pathogenic microbes in clinical and food industry settings. Contributed to the specific antibacterial mechanisms, eukaryotic cells could be similarly damaged by silver nanoparticles, which caused concerns to human health (Laux et al., 2018; Zheng et al., 2018). In recent years, a growing body of literature reports public concerns about the cytotoxicity, genotoxicity, and ecotoxicity of silver nanomaterials, factors that mainly depend on size, shape, surface property, dosimetry, and stability (e.g., the aggregation, dissolution, and release of ions; AshaRani et al., 2009; Becker et al., 2011; DeLoid et al., 2015; Mitrano et al., 2015). In this regard, the European Food Safety Agency (EFSA) has issued guidelines for the risk assessment of nano-materials to determine their suitability for (partial) application in agriculture, food, and feed (EFSA Scientific Committee, 2011). These guidelines are involved in common physicochemical methods and constantly developing analytical methods, for instance, inductively coupled plasma mass spectrometry based on laser ablation (LA-ICP-MS) for localization and quantification of metallic nanopar-

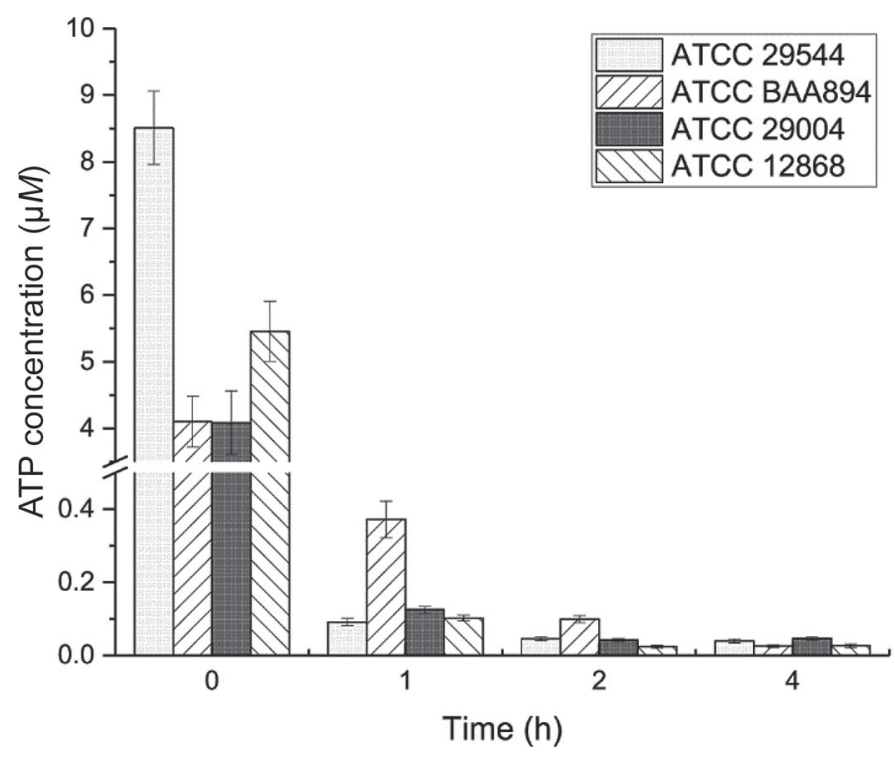

Figure 11. Changes of intracellular ATP concentrations in bacterial cells of the 4 Cronobacter sakazakii strains before $(0 \mathrm{~h})$ and after addition of silver nanoparticles at a final concentration of $200 \mathrm{mg} / \mathrm{L}$. ticles in single cells (Drescher et al., 2012). Combined with the results obtained in this study and discussions above, we propose 2 plans for potential application of the synthesized AgNP to control C. sakazakii within the PIF production environment. First, antimicrobial films composed of low-density polyethylene and synthesized silver nanoparticles (LDPE-AgNP) could be prepared through high-energy ball milling under cryogenic conditions to achieve a well-blended powder of both and then hot-pressed to films, according to Olmos et al. (2018). In fact, it has been shown that nanoparticles $>3$ to $4 \mathrm{~nm}$ in diameter cannot migrate from LDPE due to its high diffusion properties (Maia et al., 2016). In the current study, the mean size of synthesized nanoparticles was $31.2 \mathrm{~nm}$, feasible to prepare an LDPE-AgNP film with no concerning transference issues of silver nanoparticles to food. Thus, it supplies an acceptable solution to efficiently control C. sakazakii by covering the films upon the surface of equipment or facilities for PIF production. Second, an antimicrobial ecological water-borne paint could be formulated with synthesized silver nanoparticles at concentrations between 0.15 and $1 \%$ (wt/wt), according to the report of Tornero et al. (2018). This paint could be applied in food industry environments; for example, painted on the walls, to prevent potential food contamination by C. sakazakii due to direct contact with bacteria in the air or exhibit a certain inhibition zone to disrupt the reproduction of bacteria. For homogeneous distribution of AgNP in paint matrix, nanoparticles could be pre-dispersed by ultrasonic sonication in water and then added into the paint formulation. Furthermore, because of potential contact with water during production of PIF, dissolution of silver nanoparticles into ions could occur and the release of $\mathrm{Ag}^{+}$ions should be monitored before practical use; dissolved $\mathrm{Ag}^{+}$can re-form nanoparticles under slightly reductive conditions, causing an environmental hazard, even ecotoxicity, with efflux into the ecosystem (Störmer et al., 2017). In summary, nanomaterials such as AgNP have potential as an efficient means to control C. sakazakii in the food industry; however, caution is warranted due to potential safety problems. A longterm risk assessment of toxicity, including inhalation and oral toxicity, and ecotoxicity testing is needed.

\section{CONCLUSIONS}

The chemical reduction method is a practical way to synthesize silver nanoparticles. In the present study, spherical, positively charged, and face-centered cubic silver nanoparticles with a mean particle size of 31.2 $\mathrm{nm}$ were synthesized by reducing $\mathrm{Ag}^{+}$using citrate and dispersed by glycerol and PVP in alkaline conditions. These silver nanoparticles had efficient antibacterial 
activity against $C$. sakazakii strains according to the MIC and inhibition zone results. Moreover, we proposed a possible antibacterial mechanism as follows: AgNP adhere to the surface of bacteria, damaging the integrity of the cellular membrane, leading to leakage of reducing sugars and proteins from the cell. In addition, dysfunction of respiratory chain was caused through a reduction of intracellular ATP levels and inhibition of enzymatic activity of dehydrogenases, eventually causing cell death.
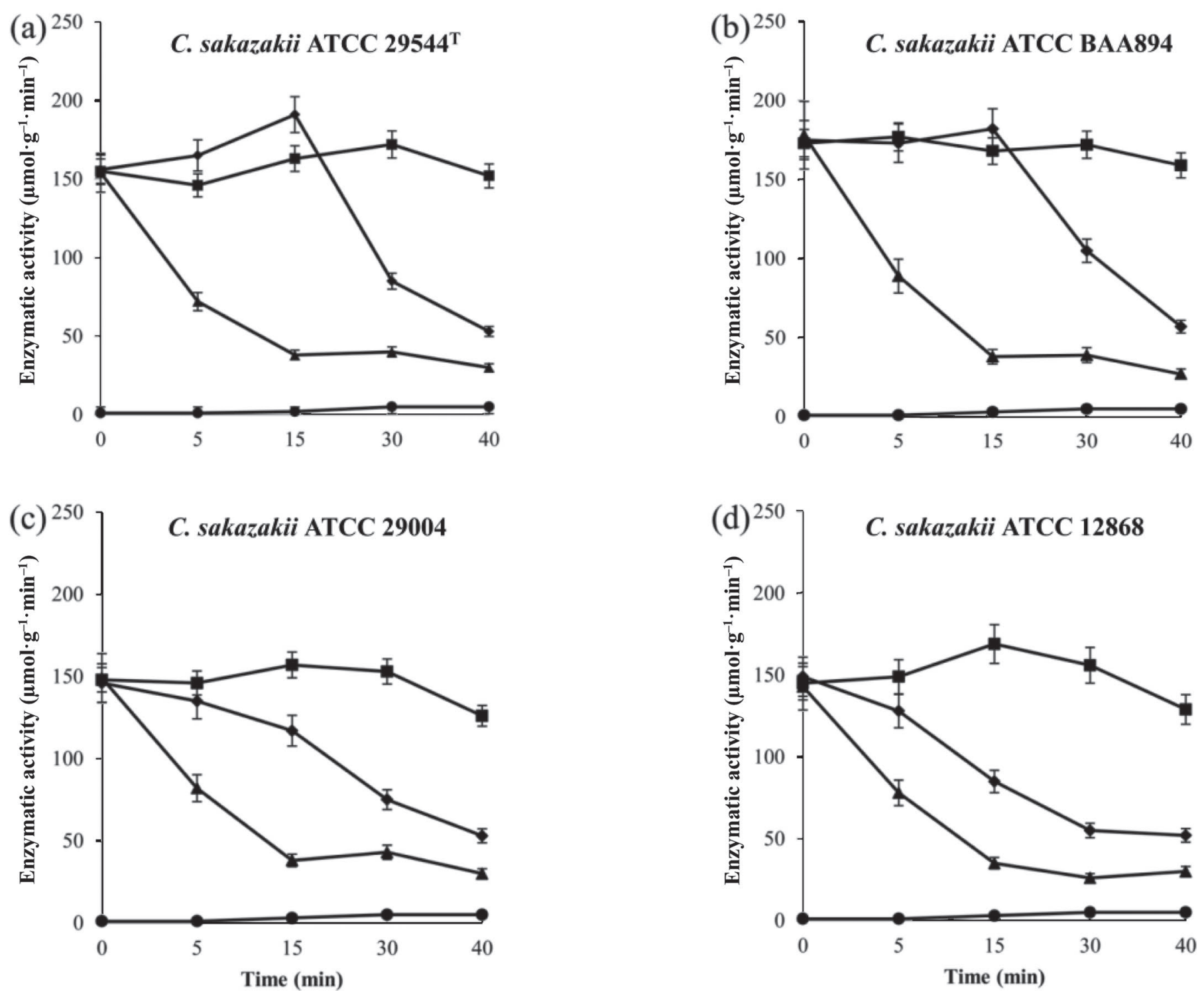

Figure 12. Changes of enzymatic activity of respiratory chain dehydrogenases for 4 Cronobacter sakazakii strains over time. The control $(+)$ group shows bacteria treated with $0.1 \mathrm{~mL}$ of PBS at $\mathrm{pH} 7.0$, the control (-) group represents bacteria boiled for 20 min to totally inactivate dehydrogenases, whereas the 200 and $1,000 \mathrm{mg} / \mathrm{L}$ groups show bacteria treated with corresponding concentrations of AgNP for a certain time individually. 


\section{ACKNOWLEDGMENTS}

This work was supported by the National High-Level Talents Special Support Program of China (810098). The authors declare that they have no competing interests.

\section{REFERENCES}

Abbaszadegan, A., Y. Ghahramani, A. Gholami, B. Hemmateenejad, S. Dorostkar, M. Nabavizadeh, and H. Sharghi. 2015. The effect of charge at the surface of silver nanoparticles on antimicrobial activity against gram-positive and gram-negative bacteria: A preliminary study. J. Nanomater. 2015:720654.

Adekunte, A., V. P. Valdramidis, B. K. Tiwari, N. Slone, P. J. Cullen, C. P. O. Donnell, and A. Scannell. 2010. Resistance of Cronobacter sakazakii in reconstituted powdered infant formula during ultrasound at controlled temperatures: A quantitative approach on microbial responses. Int. J. Food Microbiol. 142:53-59.

AshaRani, P. V., G. Low Kah Mun, M. P. Hande, and S. Valiyaveettil. 2009. Cytotoxicity and genotoxicity of silver nanoparticles in human cells. ACS Nano 3:279-290.

Awaisheh, S. S., A. A. Al-Nabulsi, T. M. Osaili, S. Ibrahim, and R. Holley. 2013. Inhibition of Cronobacter sakazakii by heat labile bacteriocins produced by probiotic LAB isolated from healthy infants. J. Food Sci. 78:M1416-1420.

Bai, J., Y. Wu, X. Liu, K. Zhong, Y. Huang, and H. Gao. 2015. Antibacterial activity of shikimic acid from pine needles of Cedrus deodara against Staphylococcus aureus through damage to cell membrane. Int. J. Mol. Sci. 16:27145-27155.

Becker, H., F. Herzberg, A. Schulte, and M. Kolossa-Gehring. 2011. The carcinogenic potential of nanomaterials, their release from products and options for regulating them. Int. J. Hyg. Environ. Health 214:231-238.

Beuchat, L. R., H. Kim, J. B. Gurtler, L. C. Lin, J. H. Ryu, and G. M. Richards. 2009. Cronobacter sakazakii in foods and factors affecting its survival, growth, and inactivation. Int. J. Food Microbiol. 136:204-213

Bot, C., and C. Prodan. 2009. Probing the membrane potential of living cells by dielectric spectroscopy. Eur. Biophys. J. 38:1049-1059

Bragg, P. D., and D. Rainnie. 1974. The effect of silver ions on the respiratory chain of Escherichia coli. Can. J. Microbiol. 20:883-889.

Carlson, C., S. M. Hussain, A. M. K. Schrand, L. Braydich-Stolle, K. L. Hess, R. L. Jones, and J. J. Schlager. 2008. Unique cellular interaction of silver nanoparticles: size-dependent generation of reactive oxygen species. J. Phys. Chem. B 112:13608-13619.

Chai, S. H., Y. Wang, Y. Qiao, P. Wang, Q. Li, C. Xia, and M. Ju. 2018. Bio fabrication of silver nanoparticles as an effective wound healing agent in the wound care after anorectal surgery. J. Photochem. Photobiol. B 178:457-462.

Dauthal, P., and M. Mukhopadhyay. 2013. Biosynthesis of palladium nanoparticles using Delonix regia leaf extract and its catalytic activity for nitro-aromatics hydrogenation. Ind. Eng. Chem. Res. $52: 18131-18139$

DeLoid, G. M., J. M. Cohen, G. Pyrgiotakis, S. V. Pirela, A. Pal, J. Liu, J. Srebric, and P. Demokritou. 2015. Advanced computational modeling for in vitro nanomaterial dosimetry. Part. Fibre Toxicol. $12: 32$

Devaraj, P., P. Kumari, C. Aarti, and A. Renganathan. 2013. Synthesis and characterization of silver nanoparticles using cannonball leaves and their cytotoxic activity against MCF-7 cell line. J. Nanotechnol. 2:421-428.

Dey, A., A. Dasgupta, V. Kumar, A. Tyagi, and A. K. Verma. 2015. Evaluation of the antibacterial efficacy of polyvinylpyrrolidone (PVP) and tri-sodium citrate (TSC) silver nanoparticles. Int. Nano Lett. 5:223-230.

Dibrov, P., J. Dzioba, K. K. Gosink, and C. C. Häse. 2002. Chemiosmotic mechanism of antimicrobial activity of $\mathrm{Ag}^{+}$in Vibrio cholerae. Antimicrob. Agents Chemother. 46:2668-2670.
Dong, X., X. Ji, H. Wu, L. Zhao, J. Li, and W. Yang. 2009. Shape control of silver nanoparticles by stepwise citrate reduction. J. Phys. Chem. C 113:6573-6576.

Drescher, D., C. Giesen, H. Traub, U. Panne, J. Kneipp, and N. Jakubowski. 2012. Quantitative imaging of gold and silver nanoparticles in single eukaryotic cells by laser ablation ICP-MS. Anal. Chem. 84:9684-9688.

EFSA Scientific Committee. 2011. Guidance on the risk assessment of the application of nanoscience and nanotechnologies in the food and feed chain. EFSA J. 9:2140.

El Badawy, A. M. R. G. Silva, B. Morris, K. G. Scheckel, M. T. Suidan, and T. M. Tolaymat. 2011. Surface charge-dependent toxicity of silver nanoparticles. Environ. Sci. Technol. 45:283-287.

El-Naggar, N. E. A., M. H. Hussein, and A. A. El-Sawah. 2017. Biofabrication of silver nanoparticles by phycocyanin, characterization, in vitro anticancer activity against breast cancer cell line and in vivo cytotxicity. Sci. Rep. 7:10844.

Endersen, L., C. Buttimer, E. Nevin, A. Coffey, H. Neve, H. Oliveira, R. Lavigne, and J. O'Mahony. 2017. Investigating the biocontrol and anti-biofilm potential of a three phage cocktail against Cronobacter sakazakii in different brands of infant formula. Int. J. Food Microbiol. 253:1-11.

Friedemann, M. 2009. Epidemiology of invasive neonatal Cronobacter (Enterobacter sakazakii) infections. Eur. J. Clin. Microbiol. Infect. Dis. 28:1297-1304.

Gomaa, E. Z. 2017. Silver nanoparticles as an antimicrobial agent: A case study on Staphylococcus aureus and Escherichia coli as models for Gram-positive and Gram-negative bacteria. J. Gen. Appl. Microbiol. 63:36-43.

Ha, J. W., and D. H. Kang. 2014. Synergistic bactericidal effect of simultaneous near-infrared radiant heating and UV radiation against Cronobacter sakazakii in powdered infant formula. Appl. Environ. Microbiol. 80:1858-1863.

Hartmann, I., P. Carranza, A. Lehner, R. Stephan, L. Eberl, and K. Riedel. 2010. Genes involved in Cronobacter sakazakii biofilm formation. Appl. Environ. Microbiol. 76:2251-2261.

Healy, B., S. Cooney, S. O'Brien, C. Iversen, P. Whyte, J. Nally, J. J. Callanan, and S. Fanning. 2010. Cronobacter (Enterobacter sakazakii): An opportunistic foodborne pathogen. Foodborne Pathog. Dis. 7:339-350.

Iversen, C., A. Lehner, N. Mullane, E. Bidlas, I. Cleenwerck, J. Marugg, S. Fanning, R. Stephan, and H. Joosten. 2007. The taxonomy of Enterobacter sakazakii: Proposal of a new genus Cronobacter gen. nov. and descriptions of Cronobacter sakazakii comb. nov. Cronobacter sakazakii ssp. sakazakii, comb. nov., Cronobacter sakazakii ssp. malonaticus ssp. nov., Cronobacter turicensis sp. nov., Cronobacter muytjensii sp. nov., Cronobacter dublinensis sp. nov. and Cronobacter genomospecies 1. BMC Evol. Biol. 7:64.

Jaradat, Z. W., W. Al Mousa, A. Elbetieha, A. Al Nabulsi, and B. D. Tall. 2014. Cronobacter spp.--opportunistic food-borne pathogens. A review of their virulence and environmental-adaptive traits. J. Med. Microbiol. 63:1023-1037.

Ji, X., X. Song, J. Li, Y. Bai, W. Yang, and X. Peng. 2007. Size control of gold nanocrystals in citrate reduction: the third role of citrate. J. Am. Chem. Soc. 129:13939-13948.

Johler, S., R. Stephan, I. Hartmann, K. A. Kuehner, and A. Lehner. 2010. Genes involved in yellow pigmentation of Cronobacter sakazakii ES5 and influence of pigmentation on persistence and growth under environmental stress. Appl. Environ. Microbiol. 76:10531061

Jyoti, K., M. Baunthiyal, and A. Singh. 2016. Characterization of silver nanoparticles synthesized using Urtica dioica Linn. leaves and their synergistic effects with antibiotics. J. Radiat. Res. Appl. Sci. 9:217-227.

Kandhai, M. C., M. W. Reij, L. G. Gorris, O. Guillaume-Gentil, and M. van Schothorst. 2004. Occurrence of Enterobacter sakazakii in food production environments and households. Lancet 363:39-40.

Kreibig, U. 2001. Electronic properties of small silver particles: the optical constants and their temperature dependence. J. Phys. F Met. Phys. 4:999. 
Kucerova, E., S. W. Clifton, X. Q. Xia, F. Long, S. Porwollik, L. Fulton, C. Fronick, P. Minx, K. Kyung, W. Warren, R. Fulton, D. Y. Feng, A. Wollam, N. Shah, V. Bhonagiri, W. E. Nash, H. P. Kymberlie, R. K. Wilson, M. McClelland, and S. J. Forsythe. 2010. Genome sequence of Cronobacter sakazakii BAA-894 and comparative genomic hybridization analysis with other Cronobacter species. PLoS One 5:e9556.

Lara, H. H., E. N. Garza-Treviño, L. Ixtepan-Turrent, and D. K. Singh. 2011. Silver nanoparticles are broad-spectrum bactericidal and virucidal compounds. J. Nanobiotechnology 9:30.

Laux, P., J. Tentschert, C. Riebeling, A. Braeuning, O. Creutzenberg, A. Epp, V. Fessard, K. H. Haas, A. Haase, H. R. Kerstin, N. Jakubowski, P. Kearns, A. Lampen, H. Rauscher, R. Schoonjans, A. Stormer, A. Thielmann, U. Muhle, and A. Luch. 2018. Nanomaterials: Certain aspects of application, risk assessment and risk communication. Arch. Toxicol. 92:121-141.

Lee, G. J., S. I. Shin, Y. C. Kim, and S. G. Oh. 2004. Preparation of silver nanorods through the control of temperature and $\mathrm{pH}$ of reaction medium. Mater. Chem. Phys. 84:197-204.

Lehner, A., K. Riedel, L. Eberl, P. Breeuwer, B. Diep, and R. Stephan. 2005. Biofilm formation, extracellular polysaccharide production, and cell-to-cell signaling in various Enterobacter sakazakii strains: aspects promoting environmental persistence. J. Food Prot. $68: 2287-2294$.

Li, W. R., X. B. Xie, Q. S. Shi, S. S. Duan, Y. S. Ouyang, and Y. B. Chen. 2011. Antibacterial effect of silver nanoparticles on Staphylococcus aureus. Biometals 24:135-141.

Li, W. R., X. B. Xie, Q. S. Shi, H. Y. Zeng, O. Y. You-Sheng, and Y. B. Chen. 2010. Antibacterial activity and mechanism of silver nanoparticles on Escherichia coli. Appl. Microbiol. Biotechnol. 85:1115-1122.

Maia, J., A. Rodríguez-Bernaldo de Quirós, R. Sendón, J. M. Cruz, A. Seiler, R. Franz, S. Catherine, L. Castle, M. Drifield, P. Mercea, P. Oldring, V. Tosa, and P. Paseiro. 2016. Determination of key diffusion and partition parameters and their use in migration modelling of benzophenone from low-density polyethylene (LDPE) into different foodstuffs. Food Addit. Contam. A Chem. Anal. Control. Expo. Risk Assess. 33:715-724.

Majeed Khan, M. A., S. Kumar, M. Ahamed, S. A. Alrokayan, and M. S. AlSalhi. 2011. Structural and thermal studies of silver nanoparticles and electrical transport study of their thin films. Nanoscale Res. Lett. 6:434.

Miller, G. L. 1959. Use of dinitrosalicylic acid reagent for determination of reducing sugar. Anal. Chem. 31:426-428.

Mitrano, D. M., S. Motellier, S. Clavaguera, and B. Nowack. 2015. Review of nanomaterial aging and transformations through the life cycle of nano-enhanced products. Environ. Int. 77:132-147.

Morones, J. R., J. L. Elechiguerra, A. Camacho, K. Holt, J. B. Kouri, J. T. Ramírez, and M. J. Yacaman. 2005. The bactericidal effect of silver nanoparticles. Nanotechnology 16:2346-2353.

Naik, R. R., S. J. Stringer, G. Agarwal, S. E. Jones, and M. O. Stone. 2002. Biomimetic synthesis and patterning of silver nanoparticles. Nat. Mater. 1:169-172.

Noh, H. J., A. Im, H. S. Kim, J. K. Sohng, C. K. Kim, Y. S. Kim, S. Cho, and Y. Park. 2012. Antibacterial activity and increased freeze-drying stability of sialyllactose-reduced silver nanoparticles using sucrose and trehalose. J. Nanosci. Nanotechnol. 12:38843895 .

Olmos, D., G. M. Pontes-Quero, A. Corral, G. González-Gaitano, and J. González-Benito. 2018. Preparation and characterization of antimicrobial films based on LDPE/Ag nanoparticles with potential uses in food and health industries. Nanomaterials (Basel) 8:60.

Pal, S., Y. K. Tak, and J. M. Song. 2007. Does the antibacterial activity of silver nanoparticles depend on the shape of the nanoparticle? A study of the gram-negative bacterium Escherichia coli. Appl. Environ. Microbiol. 73:1712-1720.

Raffi, M., F. Hussain, T. M. Bhatti, J. I. Akhter, A. Hameed, and M. M. Hasan. 2008. Antibacterial characterization of silver nanoparticles against E. coli ATCC-15224. Mater. Sci. Technol. 24:192-196.
Ramalingam, B., T. Parandhaman, and S. K. Das. 2016. Antibacterial effects of biosynthesized silver nanoparticles on surface ultrastructure and nanomechanical properties of gram-negative bacteria viz. Escherichia coli and Pseudomonas aeruginosa. ACS Appl. Mater. Interfaces 8:4963-4976.

Ranoszek-Soliwoda, K., E. Tomaszewska, E. Socha, P. Krzyczmonik, A. Ignaczak, P. Orlowski, M. Krzyzowska, G. Celichowski, and J. Grobelny. 2017. The role of tannic acid and sodium citrate in the synthesis of silver nanoparticles. J. Nanopart. Res. 19:273.

Raza, M. A., Z. Kanwal, A. Rauf, A. Sabri, S. Riaz, and S. Naseem. 2016. Size- and shape-dependent antibacterial studies of silver nanoparticles synthesized by wet chemical routes. Nanomaterials (Basel) 6:74.

Riedel, K., and A. Lehner. 2007. Identification of proteins involved in osmotic stress response in Enterobacter sakazakii by proteomics. Proteomics 7:1217-1231.

Ruparelia, J. P., A. K. Chatterjee, S. P. Duttagupta, and S. Mukherji. 2008. Strain specificity in antimicrobial activity of silver and copper nanoparticles. Acta Biomater. 4:707-716.

Schwechheimer, C. and M. J. Kuehn. 2015. Outer-membrane vesicles from Gram-negative bacteria: biogenesis and functions. Nat. Rev. Microbiol. 13:605-619.

Sedmak, J. J., and S. E. Grossberg. 1977. A rapid, sensitive, and versatile assay for protein using Coomassie brilliant blue G250. Anal. Biochem. 79:544-552.

Shi, C., Y. Sun, Z. Zheng, X. Zhang, K. Song, Z. Jia, Y. Chen, M. Yang, X. Liu, and R. Dong. 2016. Antimicrobial activity of syringic acid against Cronobacter sakazakii and its effect on cell membrane. Food Chem. 197:100-106.

Sikder, M., J. R. Lead, G. T. Chandler, and M. Baalousha. 2018. A rapid approach for measuring silver nanoparticle concentration and dissolution in seawater by UV-Vis. Sci. Total Environ. 618:597-607.

Störmer, A., J. Bott, D. Kemmer, and R. Franz. 2017. Critical review of the migration potential of nanoparticles in food contact plastics. Trends Food Sci. Technol. 63:39-50.

Torlak, E., and D. Sert. 2013. Inactivation of Cronobacter by gaseous ozone in milk powders with different fat contents. Int. Dairy J. $32: 121-125$.

Tornero, A. F., M. G. Blasco, M. C. Azqueta, C. F. Acevedo, C. S Castro, and S. R. López. 2018. Antimicrobial ecological waterborne paint based on novel hybrid nanoparticles of zinc oxide partially coated with silver. Prog. Org. Coat. 121:130-141.

van Breemen, R. B., and Y. Li. 2005. Caco-2 cell permeability assays to measure drug absorption. Expert Opin. Drug Metab. Toxicol. 1:175-185. (J).

Vance, M. E., T. Kuiken, E. P. Vejerano, S. P. McGinnis, M. F. Hochella Jr., D. Rejeski, and M. S. Hull. 2015. Nanotechnology in the real world: Redeveloping the nanomaterial consumer products inventory. Beilstein J. Nanotechnol. 6:1769-1780.

Wang, H., X. Qiao, J. Chen, X. Wang, and S. Ding. 2005. Mechanisms of PVP in the preparation of silver nanoparticles. Mater. Chem. Phys. 94:449-453.

Yemis, G. P., F. Pagotto, S. Bach, and P. Delaquis. 2011. Effect of vanillin, ethyl vanillin, and vanillic acid on the growth and heat resistance of Cronobacter species. J. Food Prot. 74:2062-2069.

You, C., C. Han, X. Wang, Y. Zheng, Q. Li, X. Hu, and H. Sun 2012. The progress of silver nanoparticles in the antibacterial mechanism, clinical application and cytotoxicity. Mol. Biol. Rep. 39:9193-9201.

Yuroff, A. S., G. Sabat, and W. Hickey. 2003. Transporter-mediated uptake of 2-chloro-and 2-hydroxybenzoate by Pseudomonas huttiensis strain D1. Appl. Environ. Microbiol. 69:7401-7408.

Zheng, K., M. I. Setyawati, D. T. Leong, and J. Xie. 2018. Antimicrobial silver nanomaterials. Coord. Chem. Rev. 357:1-17. 